\title{
Comparisons of WRF/Chem simulations in Mexico City with ground-based RAMA measurements during the 2006-MILAGRO
}

\author{
Y. Zhang ${ }^{1}$, M. K. Dubey ${ }^{2}$, S. C. Olsen ${ }^{3}$, J. Zheng ${ }^{4}$, and R. Zhang ${ }^{4}$ \\ ${ }^{1}$ Climate Impacts Group, University of Washington, Seattle, Washington, USA \\ ${ }^{2}$ Earth and Environmental Science Division, Los Alamos National Laboratory, Los Alamos, New Mexico, USA \\ ${ }^{3}$ Department of Atmospheric Sciences, University of Illinois at Urbana-Champaign, Urbana, Illinois, USA \\ ${ }^{4}$ Department of Atmospheric Sciences, Texas A\&M University, College Station, Texas, USA
}

Received: 1 October 2008 - Published in Atmos. Chem. Phys. Discuss.: 15 January 2009

Revised: 18 May 2009 - Accepted: 18 May 2009 - Published: 11 June 2009

\begin{abstract}
Simulations using the fully coupled WRF/Chem (Weather Research and Forecasting - Chemistry) model at 3-km resolution in Mexico City have been performed to examine the temperature, relative humidity, wind, and gaseous criteria pollutants $\left(\mathrm{CO}, \mathrm{O}_{3}, \mathrm{NO}, \mathrm{NO}_{2}\right.$, and $\left.\mathrm{NO}_{\mathrm{y}}\right)$ during the MCMA-2006/MILAGRO field campaign. Comparison of the model simulations with measurements from the groundbased air quality monitoring network (RAMA) is presented. The model resolves reasonably well the observed surface temperature, relative humidity and wind speed; however, large discrepancies are identified between the simulated and the observed surface wind direction for wind speeds below $2 \mathrm{~m} \mathrm{~s}^{-1}$. The simulated chemical species concentrations $\left(\mathrm{CO}, \mathrm{O}_{3}, \mathrm{NO}, \mathrm{NO}_{2}\right.$, and $\left.\mathrm{NO}_{\mathrm{y}}\right)$ compare favorably with the observations. Simulated $\mathrm{O}_{3}$ concentrations agree especially well with the observations. The simulated 10 VOC species compare generally favorably with the observations at the T0 supersite although lower correlation coefficients and larger biases exist for propene, acetone and propanal, isoprene, and c10-aromatics when compared to the other VOC species. The model performs much better during daytime than nighttime for both chemical species and meteorological variables, although the model tends to underestimate daytime temperature and relative humidity. Simulations using combinations of the available PBL schemes and land surface models (LSMs) do not show a preferred combination in reproducing the observations. The simulated meteorological fields under the $\mathrm{O}_{3}$-South, $\mathrm{O}_{3}$-North and EI Norte weather
\end{abstract}

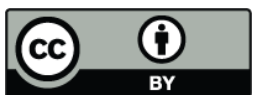

Correspondence to: Y. Zhang (yongxin@u.washington.edu) episodes exhibit similar correlation coefficients and biases for the same variable. However, the model performs well for the $\mathrm{O}_{3}$-South episode but inferiorly for the El Norte events in resolving the observed chemical species.

\section{Introduction}

The largest contribution to anthropogenic emissions comes from urban sources that emit a large variety of gaseous and particulate species (Seinfeld and Pandis, 1998). The export of these pollutants from urban to regional and global environments is a major concern because of wide-ranging potential consequences for human health, ecosystems, weather modification, visibility degradation, changes in radiative forcing, and tropospheric oxidation capacity. Characterizing the impacts of urban pollutants requires detailed modeling studies, in addition to extensive observational analyses. As one of the world's most populous and fastest growing megacities, the Mexico City Metropolitan Area (MCMA) provides a good example for studying how urban emissions and transport affect vegetation, human health, and regional climate (BorjaAburto et al., 1997; Romieu et al., 1999; Raga et al., 2001; Molina and Molina, 2002).

Mexico City is located at $19^{\circ} \mathrm{N}, 99^{\circ} \mathrm{W}$ in a basin with an average elevation of $2.2 \mathrm{~km}$ above sea level. Except for a broad opening to the north and a narrow gap to the south, it is surrounded by high mountains effectively creating a barrier to large-scale circulations and isolating the city from the winds of synoptic weather systems at low levels. Conditions are favorable for high pollution episodes in Mexico City, given that nearly 20 million people are living within the

Published by Copernicus Publications on behalf of the European Geosciences Union. 
Mexico City Valley and the emissions from approximately 4 million vehicles (burning over 47 million liters of fuel per day) and the emissions from industrial and commercial activities that account for almost $30 \%$ of the GNP (Gross National Product) of Mexico (Molina and Molina, 2002) are released into the valley. Its tropical location also contributes to high pollution levels as incident radiation is generally strong and does not vary significantly throughout the year. Ozone and particulate matter (PM) pollution is of particular concern in Mexico City. Measured concentrations of ozone violate the Mexican 1-h air quality standard of $110 \mathrm{ppbv}$ on approximately $64 \%$ of the days of the year (INE, 2007). Additionally, the increased UV radiation due to the high elevation of the basin favors ozone production (Raga and Raga, 2000; Molina and Molina, 2002; Munoz-Alpizar et al., 2003). Meteorological studies suggest that the Mexico City Valley is well ventilated overnight and that the local air circulations associated with the complex terrain control the transport and dispersion of pollutants in the area (Fast and Zhong, 1998; Doran et al., 1998; Whiteman et al., 2000; Doran and Zhong, 2000; Jazcilevich et al., 2003; de Foy et al., 2005, 2006a). The complex terrain, distinct geographical location, and high pollutant emissions register Mexico City as a perfect testbed for regional dynamic and chemistry model.

A review of past and recent large field measurement campaigns in Mexico City is given elsewhere (Molina and Molina, 2002; Molina et al., 2007). A comprehensive set of meteorological and chemical measurements within the MCMA were made during the MCMA-2003 field campaign that took place in 31 March - 4 May 2003 (Molina et al., 2007). As a continuation of the MCMA-2003 campaign, the MCMA-2006 field campaign was carried out during 3 March through 30 March 2006 to provide ground-based measurements of a large suite of gas species and aerosol chemical and physical properties, as one of the components of the MILAGRO (Megacity Initiative: Local and Global Research Observations) campaign (Molina et al., 2008).

Several photochemical modeling studies have been carried out in the MCMA in recent years. West et al. (2004) examined ozone photochemistry and hydrocarbon emissions in the MCMA using the California Institute of Technology/Carnegie Mellon University (CIT) airshed model for six 2-day periods during the measurement campaign of March 1997. They noted that a best fit to the measurements is found when increasing the official emissions of $\mathrm{CO}$ and VOCs (volatile organic compounds) for 1998 by a factor of 2 and 3 , respectively. Tie et al. (2007) used a fully coupled WRF/Chem (Weather Research and Forecasting - Chemistry) model to study the origin and evolution of high ozone events in the MCMA under clear sky conditions during 6 May through 11 May 2003. They showed that the strong diurnal cycle in ozone is mainly attributable to photochemical variations, while diurnal cycles of $\mathrm{CO}$ and $\mathrm{NO}_{\mathrm{x}}$ mainly result from variations of emissions and boundary layer height. Lei et al. (2007) conducted an episodic simulation to char- acterize midday $\mathrm{O}_{3}$ photochemical production and its sensitivity to emission changes of $\mathrm{O}_{3}$ precursors in the MCMA using the Comprehensive Air Quality Model with extensions $(\mathrm{CAMx})$. They pointed out that high $\mathrm{O}_{\mathrm{x}}\left(\mathrm{O}_{3}+\mathrm{NO}_{2}\right)$ photochemical production rates of $10-80 \mathrm{ppb} / \mathrm{h}$ are due to the high reactivity of VOCs in which alkanes, alkenes, and aromatics exert comparable contributions.

This work applies the fully coupled WRF/Chem in Mexico City to examine and compare the modeled temperature, relative humidity, wind and gaseous criteria pollutants $(\mathrm{CO}$, $\mathrm{O}_{3}, \mathrm{NO}, \mathrm{NO}_{2}$, and $\mathrm{NO}_{\mathrm{x}}$ ) at 3-km resolution with the groundbased measurements at monitoring sites of Mexico City's air quality monitoring network (RAMA) during the entire period of the MILAGRO field campaign. Comparisons between the observed and modeled VOC species at the T0 supersite during MILAGRO are also included. The VOC species were measured by a PTR-MS (proton transfer reaction - mass spectrometry) instrument (Fortner et al., 2009). In this work, month-long simulations are carried out for building statistics and the model performance is evaluated under various weather conditions prevalent during the MILAGRO campaign. Sections 2 and 3 contain brief descriptions of the model and the emissions inventory for Mexico City, respectively. Surface observations and experimental design are discussed in Sect. 4. Analyses of the model simulations and comparisons with observations are presented in Sect. 5. Major conclusions are presented in Sect. 6 .

\section{Model descriptions}

The dynamical model used is the WRF model (http://www. wrf-model.org). It has several options for physical parameterizations suitable for a broad spectrum of applications. WRF utilizes a fully mass- and scalar-conserving coordinate system that is widely used in air quality prediction systems (Bacon et al., 2000; Satoh, 2002). The physics package in WRF consists of microphysics, cumulus parameterization, planetary boundary layer (PBL), land surface, longwave and shortwave radiation.

The available microphysics options within WRF include the Kessler scheme, the Lin et al. scheme, WRF SingleMoment schemes, Eta scheme, and the Thompson et al. scheme (Skamarock et al., 2006). The available PBL parameterizations are the YSU scheme (Hong et al., 2006) which is an updated version of Hong and Pan (1996) and MYJ scheme (Mellor and Yamada, 1982; Janjic, 1996, 2002). The land surface models (LSMs) include the NOAH LSM (Chen and Dudhia, 2001) and the RUC LSM (Smirnova et al., 1997, 2000). Atmospheric radiation schemes include the Rapid Radiative Transfer Model (RRTM) for longwave (Mlawer et al., 1997), the Dudhia shortwave scheme (Dudhia, 1989) and the Goddard shortwave scheme (Chou and Suarez, 1994).

The fully coupled chemistry within the WRF model, referred to as WRF/Chem, was developed at NOAA (National 
Oceanic and Atmospheric Administration) (Grell et al., 2005). Fast et al. (2006) updated WRF/Chem by incorporating complex gas-phase chemistry, aerosol treatments, and photolysis schemes. In WRF/Chem, the air quality component is fully consistent with the meteorological component; both components use the same transport scheme (mass and scalar preserving), the same grid (horizontal and vertical components), the same physical schemes for subgrid-scale transport, and the same time step for transport and vertical mixing.

There are several different chemistry, aerosol, and photolysis schemes to choose from in WRF/Chem. The chemistry packages are the Regional Acid Deposition Model version 2 (RADM2) chemical mechanism (Stockwell et al., 1990; Chang et al., 1989) and the Carbon Bond Mechanism (CBM-Z) photochemical parameterization (Zaveri and Peters, 1999). The aerosol mechanisms include the Modal Aerosol Dynamics Model for Europe (MADE, Ackermann et al., 1998) coupled with the Secondary Organic Aerosol Model (SORGAM) aerosol parameterization (Schell et al., 2001) and the Model for Simulating Aerosol Interactions and Chemistry (MOSAIC-4 or 8 bins) sectional model aerosol parameterization (Zaveri et al., 2008). One may choose either the Madronich photolysis scheme (Madronich, 1987) or the Fast-J radiation scheme (Wild et al., 2000).

In this work, the model runs for the entire MILAGRO period were conducted using the Lin et al. microphysics parameterization, the NOAH LSM and the YSU PBL scheme together with the CBM-Z Chemical mechanism and the Madronich photolysis scheme. Cumulus parameterization was not used in our simulations at $3-\mathrm{km}$ resolution. Atmospheric shortwave and longwave radiations were computed by the Dudhia scheme and by the RRTM scheme, respectively. These options were chosen based on sensitivity studies and our experiences with WRF and WRF/Chem. Model stability and computation time were also taken into account when choosing the physical and chemistry options for the runs.

\section{Emissions inventory}

The emissions inventory used in this study was gridded based on the official, bottom-up emissions inventory for the MCMA for the year 2004 (CAM, 2006). Total annual emitted masses of VOCs, CO and nitrogen oxides $\left(\mathrm{NO}_{\mathrm{x}}=\mathrm{NO}+\mathrm{NO}_{2}\right)$ were distributed across mobile, point source and area source categories and were transformed into spatially and temporally resolved and chemically speciated emissions fields following the database and procedures in West et al. (2004).

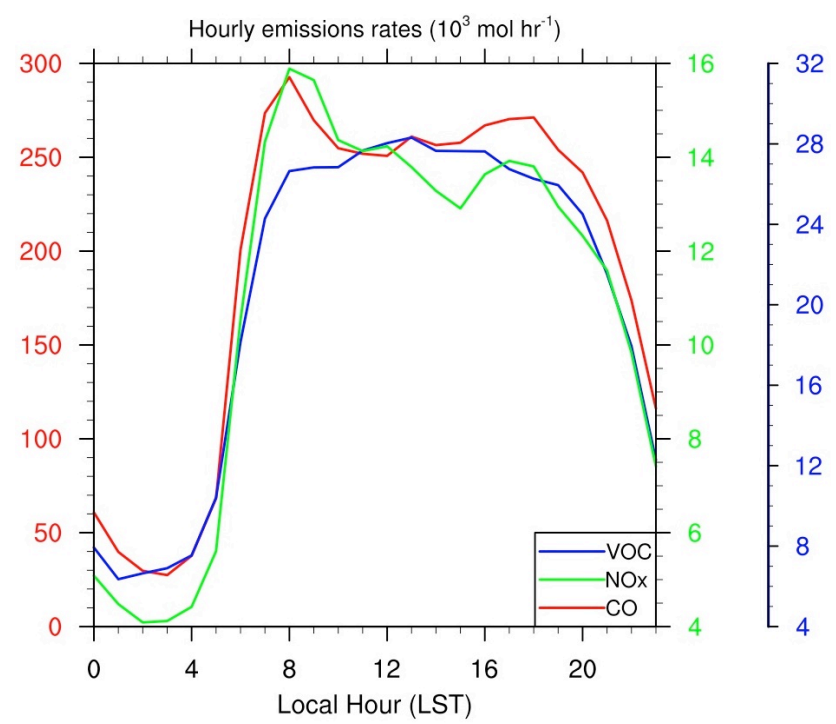

Fig. 1. Hourly emissions rates for $\mathrm{CO}$ (red line), $\mathrm{NO}_{\mathrm{x}}\left(=\mathrm{NO}+\mathrm{NO}_{2}\right.$, green line), and VOCs (blue line) summed over the entire MCMA, with y-axis color labeled accordingly.

Upgrades of the spatial distribution of mobile and area source emissions fields were performed using a grid spacing of $2.25 \mathrm{~km}$, in which more detailed road type information in each grid cell and improved population distribution were taken into account (Lei et al., 2007). The VOC emissions rates in the emissions inventory were examined based on the speciated VOC measurements in MCMA-2003 and were adjusted using scaling factors ranging from 1 to 9 to match the observed magnitude and distributions (Table 2 in Lei et al., 2007). The current emissions inventory also includes estimates of biogenic emissions. Emissions rates outside of the MCMA were set to zero.

The hourly emissions rates in this inventory were considered to be representative of a typical weekday in Mexico City. Weekend and holiday emissions were modified from weekday emissions on the basis of information from a variety of sources and experts in Mexico (West et al., 2004; de Foy et al., 2007; Lei et al., 2007). Since there were no detailed measurements on daily changes of source categories in Mexico City, the emissions data for weekdays were varied uniformly for all sources to get the emissions rates for weekends and holidays, keeping the same spatial and temporal distributions. For Saturday and Sunday, the emissions data were obtained by scaling the total weekday emissions by $85 \%$ and $75 \%$, respectively. For holidays, the emissions data were obtained by scaling the total weekday emissions by $90 \%$. Figure 1 shows the hourly emissions rates of CO, $\mathrm{NO}_{\mathrm{x}}$ and VOCs for a typical weekday summed over the entire MCMA. 


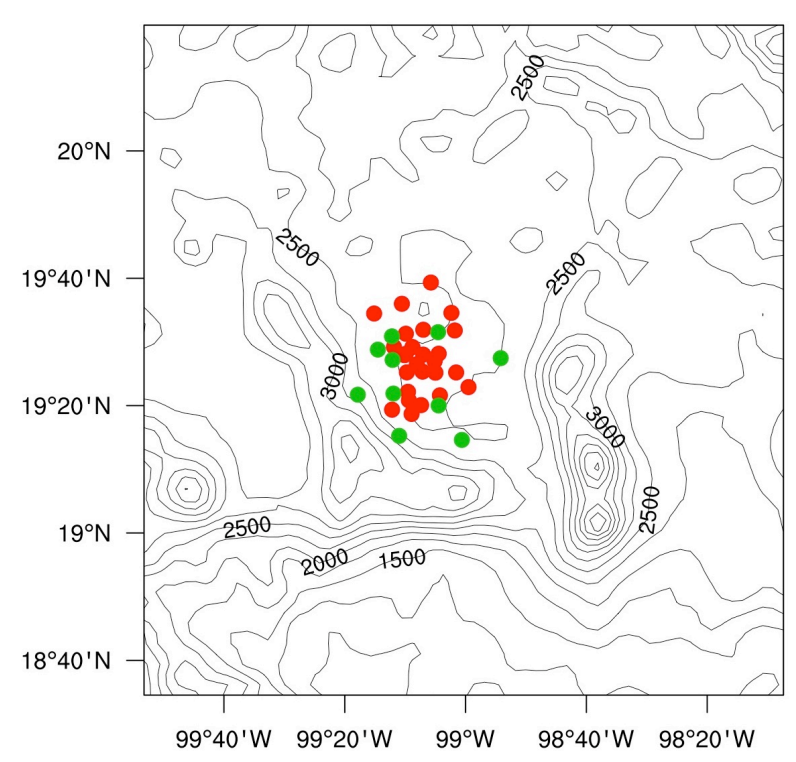

Fig. 2. WRF/Chem model domain at 3-km resolution and terrain height $(\mathrm{m})$. Terrain contour interval is $250 \mathrm{~m}$. Thirty six groundbased stations within the RAMA monitoring network are represented by color filled circles. Red circles indicate where only chemical species were measured while green circles indicate where both meteorological variables and chemical species were measured.

\section{Surface observations and experimental design}

\subsection{Surface observations}

The locations of the 36 ground-based stations within the RAMA monitoring network are shown in Fig. 2. Geographic coordinates of each station are available online (http://www. sma.df.gob.mx/simat/). Not all variables were reported at each station during the MILAGRO campaign. Four meteorological variables, temperature, relative humidity, wind direction, and wind speed were measured at 10 stations. Chemical species were measured at various stations: $\mathrm{CO}$ at 16 stations, $\mathrm{O}_{3}$ at 15 stations, $\mathrm{NO}, \mathrm{NO}_{2}$ and $\mathrm{NO}_{\mathrm{x}}$ at 12 stations, $\mathrm{SO}_{2}$ at 14 stations, $\mathrm{PM}_{10}$ at 8 stations, and $\mathrm{PM}_{2.5}$ at 4 stations. Measurements of $\mathrm{NO}_{\mathrm{x}}$ using the chemiluminescence technique more accurately represent $\mathrm{NO}_{\mathrm{y}}\left(\mathrm{NO}_{\mathrm{x}}\right.$ plus $\mathrm{NO}_{\mathrm{x}}$ oxidation products). Therefore, the measured $\mathrm{NO}_{\mathrm{x}}$ will be compared with the modeled $\mathrm{NO}_{\mathrm{y}}$. Analyses and simulations of $\mathrm{PM}_{10}$ and $\mathrm{PM}_{2.5}$ will be the focus of a future work. VOCs were not measured at the RAMA stations, but we used VOC measurements from a PTR-MS at the T0 site during 5-23 March and 26-30 March (Zhao and Zhang, 2004; Fortner et al., 2009). The T0 site is located at the Instituto Mexicano del Petroleo (IMP, $19^{\circ} 29^{\prime} \mathrm{N}, 9^{\circ} 09^{\prime}$ ). We examined 10 VOC species for which both the measurements and model output are available, including propene, acetaldehyde, c4alkenes, acetone and propanal, isoprene, methylethyl ketone, butanal and methylglyoxal, benzene, toluene, c-9 aromatics, and c10-aromatics.

\subsection{Experimental design}

WRF/Chem was configured for Mexico City and its adjacent areas at 3-km resolution with a domain size of $189 \times 198 \mathrm{~km}^{2}$ (Fig. 2). This model domain features mountainous terrain and high elevation surroundings. The model runs were initialized at 00:00 UTC (18:00 LST, Local Standard Time) each day during 3-30 March 2006 and were carried out for a 36-h simulation. The first 6-h of the model simulations were discarded as model spin-up. The initial and lateral boundary conditions for meteorology were interpolated from the NCEP Final Analysis data (http://www.nomad3. ncep.noaa.gov/ncep_data/) at $1^{\circ}$ resolution with a 6-hourly update. Model default profiles for chemical and aerosol species were used as the initial pollutant concentrations at the start of each model run. The initial background conditions for some of the trace gases are: $\mathrm{CO}, 80 \mathrm{ppbv} ; \mathrm{O}_{3}, 30 \mathrm{ppbv}$; $\mathrm{NO}, 0.08$ ppbv; and $\mathrm{NO}_{2}, 0.2 \mathrm{ppbv}$. We performed sensitivity studies using various spin-up time (i.e., 6-h, 12-h and 24-h) and using the chemistry data from the previous day simulations. We did not notice large differences in the simulated surface concentrations for chemical species in the MCMA, which suggests that our simulations were not sensitive to initial chemical conditions as also found by others (West et al., 2004; Fast and Zhong, 1998; de Foy et al., 2006c). 31 vertical levels were used in WRF/Chem with the highest resolution $(\sim 10-100 \mathrm{~m})$ in the boundary layer. The model top was fixed at $50 \mathrm{mb}$. Sensitivity tests with higher vertical resolution (62 levels) did not produce appreciable improvements over the 31 vertical levels (not shown).

\section{Results}

\subsection{Daytime and nighttime performance statistics}

In the following we use the correlation coefficient (denoted as CC) and average normalized bias (denoted as ANB) (West et al., 2004) as a quantitative measure of model observation agreement for the meteorological variables and chemical species. The ANB is defined as the average residual divided by the average measurement:

$$
\mathrm{ANB}=\frac{\frac{1}{N} \sum_{i=1}^{N}\left(x_{m}^{i}-x_{o}^{i}\right)}{\frac{1}{N} \sum_{i=1}^{N} x_{o}^{i}}=\frac{\sum_{i=1}^{N}\left(x_{m}^{i}-x_{o}^{i}\right)}{\sum_{i=1}^{N} x_{o}^{i}}
$$

where $N$ is the total number of observations at all stations combined, $x_{o}^{i}$ and $x_{m}^{i}$ are the ith observation and simulation, respectively. This definition weighs overestimates and underestimates equally in concentration units for chemical species; an overestimate of one ppbv together with an underestimate of one ppbv would result in an ANB of zero. The traditional ANB (Harley et al., 1993; Winner and Cass, 1999) tends to weight overestimates more than underestimates (Seigneur et 
al., 2000) and may lead to misleading conclusions when the observed concentrations are small such as at night.

Table 1 presents the performance statistics (means, correlation coefficients and average normalized bias) for predictions of chemical species $\left(\mathrm{CO}, \mathrm{O}_{3}, \mathrm{NO}, \mathrm{NO}_{2}, \mathrm{NO}_{\mathrm{y}}\right.$, and $\left.\mathrm{SO}_{2}\right)$ as well as temperature, relative humidity, wind speed and wind direction, calculated for all monitoring stations that reported valid measurements. The performance statistics were computed for all days during MILAGRO as well as separately for daytime and nighttime. Table 2 presents the performance statistics for predictions of 10 VOC species.

\subsubsection{Meteorological variables}

Although the simulated surface temperature correlates well with the observations during the entire MILAGRO period $(\mathrm{CC}=0.94)$, the correlation coefficient changes from 0.93 to 0.83 from daytime to nighttime (see Table 1), indicating lower model performance at night. Cold biases on the order of $1-2^{\circ} \mathrm{C}$ are noted with the largest biases occurring in daytime. Cold biases in WRF have been reported (Cheng and Steenburgh, 2005; Case et al., 2008). However, the reason for the cold biases is not clear. Several possible reasons may be in order. Firstly, there are deficiencies in model physics. Secondly, these monitoring stations are located in urban areas where specification of the properties of the underlying surfaces (i.e., albedo, roughness length, heat capacity, soil moisture, etc.) generally contains large uncertainties in weather models (de Foy et al., 2006b). Under weak synoptic conditions as is generally the case for Mexico in spring, surface properties play an important role in forcing and influencing local circulations and weather. Thirdly, 3-km resolution used for this study is not fine enough to resolve smallscale circulations in an urban environment. Lastly, the urban infrastructure effect that has been shown to play a non-trivial role in defining local circulations (Chin et al., 2005) is not included here.

The correlation coefficient for surface relative humidity is 0.82 during the entire MILAGRO period and is 0.84 during daytime but becomes 0.70 during nighttime (Table 1). Large daytime dry biases and relatively small nighttime wet biases are noted. Model daytime dry and cold biases as noted earlier appear to suggest excessive mixing in the model simulations as excessive mixing would bring down too much dry and cool air from aloft.

The simulated and observed surface wind speeds are rather low on average $\left(\sim 2 \mathrm{~m} \mathrm{~s}^{-1}\right)$ during MILAGRO (Table 1 and Fig. 3a). The correlation coefficient is 0.59 for all days while it is 0.72 in daytime and 0.36 at nighttime. Model overestimation of the observed wind speed is evident at all times especially during nighttime when the average normalized bias reaches $37.3 \%$. The poor model performance at nighttime may be partly related to the fact that surface winds are generally weak at night and that the model is unable to resolve weak winds realistically. Time series of surface wind speed at monitoring stations (Fig. 3b) indicate that the model captures well the diurnal cycle of the observations.

For surface wind direction, the correlation coefficient is $0.33,0.31$ and 0.22 for all days, daytime and nighttime, respectively (Table 1$)$. The ANB is small $(<6 \%)$ largely because the observed mean is large (see Eq. 1). A scatter plot of the observed and simulated wind direction (Fig. 3c) reveals a large spread of data. When only those points with the observed and simulated wind speeds greater than $2 \mathrm{~m} \mathrm{~s}^{-1}$ are considered (Fig. 3d), spread of the points is contained appreciably and the correlation coefficient increases to 0.49 .

\subsubsection{Chemical species}

The correlation coefficient of the simulated and observed $\mathrm{CO}$ concentration is 0.51 for the entire MILAGRO period, 0.62 for daytime and 0.25 for nighttime (Table 1). The lower model performance at nighttime is also noted for meteorological variables as discussed above and will be examined further in Sect. 5.3. Table 1 also shows large model underestimation of the observed CO concentration for daytime. Deficiencies in model physics in realistically resolving dynamical processes and uncertainties in the spatial distributions of the emissions rates may be responsible for the model underestimation of daytime $\mathrm{CO}$ concentration.

The correlation coefficient for $\mathrm{O}_{3}$ is relative high at 0.77 with an ANB of $7.1 \%$ for the entire MILAGRO period (Table 1). During nighttime, the correlation coefficient is 0.45 with large model overestimation $(\mathrm{ANB}=65.6 \%)$. This nighttime overestimation is likely due to the model underestimation of nighttime $\mathrm{NO}$ as will be discussed shortly since NO is needed in the titration process $\left(\mathrm{NO}+\mathrm{O}_{3}->\mathrm{NO}_{2}\right)$ to react with $\mathrm{O}_{3}$.

The correlation coefficient for $\mathrm{NO}, \mathrm{NO}_{2}$ and $\mathrm{NO}_{\mathrm{y}}$ during the entire MILAGRO period is $0.45,0.43$ and 0.51 , respectively, with model underestimation noted for $\mathrm{NO}$ and $\mathrm{NO}_{\mathrm{x}}$ and model overestimation for $\mathrm{NO}_{2}$ (Table 1). Nighttime degradation in model performance is evident with noticeably reduced correlation coefficients when compared to daytime. NO is underestimated by the model for both daytime and nighttime while $\mathrm{NO}_{2}$ is underestimated for daytime but overestimated for nighttime. Uncertainties in emissions rates of $\mathrm{NO}$ and $\mathrm{NO}_{2}$ and deficiencies in model chemistry parameterization (e.g., conversion between $\mathrm{NO}$ and $\mathrm{NO}_{2}$ ) may be responsible for these model biases. It is also possible that the model simulates a less reactive atmosphere than the real world, which would slow down the formation of $\mathrm{N}$ containing compounds after photochemistry becomes inactive.

In terms of VOC species during the entire MILAGRO period, the correlation coefficients are 0.26 for propene, 0.52 for acetaldehyde, 0.41 for c4-alkenes, 0.24 for acetone and propanal, 0.23 for isoprene, 0.45 for the combined methylethyl ketone, butanal and methylglyoxal, 0.49 for benzene, 0.42 for toluene, 0.50 for c 9 -aromatics, and 0.56 for 

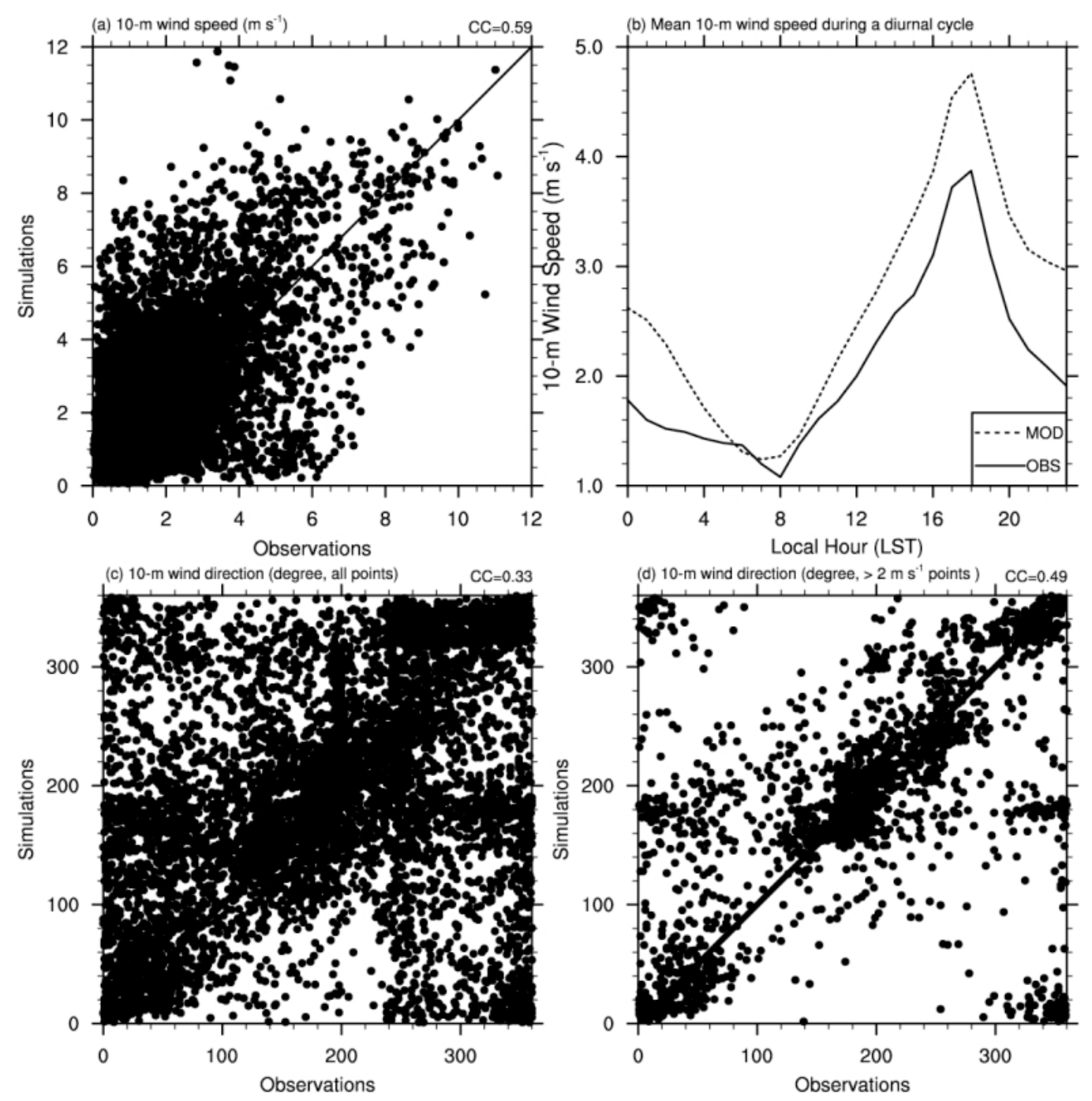

Fig. 3. Observed and WRF/Chem simulated surface wind speed $\left(\mathrm{m} \mathrm{s}^{-1}\right)$ : (a) scatter plot and (b) diurnal cycle averaged over the monitoring stations that reported valid measurements during MILAGRO. Scatter plot of the observed and WRF/Chem simulated surface wind direction (degree) during MILAGRO: (c) for all points and (d) for the points with the observed and simulated wind speed greater than $2 \mathrm{~m} \mathrm{~s}^{-1}$. CC refers to correlation coefficient.

c10-aromatics. Noticeable model overestimation is noted for c10-aromatic for which ANB is $147 \%$. The model also overestimates acetone and propanal (i.e., $\mathrm{ANB}=26 \%$ ). For propene, methylethyl ketone, butanal and methylglyoxal, and benzene, large discrepancies exist between the model simulations and measurement values.

Significant nighttime discrepancy is evident in terms of correlation coefficients for VOC species when compared to the entire MILAGRO period and daytime (Table 2). For most of the VOC species, there is little correlation or nearly out-ofphase correlation between the model simulations and observations during nighttime. In addition to lower fluctuations of chemical concentrations at night that can bring in lower correlation coefficients, it is possible that uncertainties in large- scale dynamic fields, model deficiencies in physics, and uncertainties in emissions inventory all contribute to the night degradation in model performance. It has been suggested that, for VOCs with highly localized distributions and short lifetimes in the PBL, the PBL height is critical to simulate their concentrations (Lei et al., 2004; Li et al., 2007).

The results of this analysis indicate that the WRF/Chem simulations represent the observed meteorological variables and major chemical species reasonably well during the MILAGRO period. The model performs especially well in resolving the observed $\mathrm{O}_{3}$ concentrations as the correlation coefficient between the simulated and observed $\mathrm{O}_{3}$ is the largest among all the chemical species. Large differences in model performance are noted between daytime and nighttime. The 
Table 1. Performance statistics for predictions of T, RH, WS, WD, $\mathrm{CO}, \mathrm{O}_{3}, \mathrm{NO}, \mathrm{NO}_{2}$, and $\mathrm{NO}_{\mathrm{y}}$.

\begin{tabular}{|c|c|c|c|c|c|c|c|c|c|c|}
\hline & & $\mathrm{T}^{c}$ & RH & WS & WD & $\mathrm{CO}^{d}$ & $\mathrm{O}_{3}$ & NO & $\mathrm{NO}_{2}$ & $\mathrm{NO}_{x}^{e}$ \\
\hline \multirow{4}{*}{ All } & MeanX $X_{o}^{a}$ & 17.0 & 43.9 & 2.1 & 185. & 1.3 & 32.0 & 30.4 & 35.3 & 65.7 \\
\hline & MeanX $_{m}^{a}$ & 16.5 & 41.6 & 2.6 & 191. & 1.2 & 34.3 & 21.9 & 36.1 & 59.1 \\
\hline & $\mathrm{CC}^{b}$ & 0.94 & 0.82 & 0.59 & 0.33 & 0.51 & 0.77 & 0.45 & 0.43 & 0.51 \\
\hline & $\operatorname{ANB}(\%)^{b}$ & -3.2 & -5.2 & 27.6 & 3.0 & -8.3 & 7.1 & -28 & 2.1 & -9.9 \\
\hline \multirow{4}{*}{ Daytime } & MeanX $_{o}$ & 20.2 & 36.5 & 2.3 & 158. & 1.4 & 49.0 & 30.1 & 37.0 & 67.0 \\
\hline & MeanX $_{m}$ & 19.4 & 31.3 & 2.8 & 166. & 1.2 & 46.5 & 23.6 & 30.0 & 54.9 \\
\hline & $\mathrm{CC}$ & 0.93 & 0.84 & 0.72 & 0.31 & 0.62 & 0.76 & 0.60 & 0.55 & 0.65 \\
\hline & $\operatorname{ANB}(\%)$ & -4.0 & -14 & 21.4 & 5.3 & -13 & -5.0 & -22 & -19 . & -18 \\
\hline \multirow{4}{*}{ Nighttime } & MeanX $_{o}$ & 13.2 & 52.6 & 1.8 & 217. & 1.1 & 12.0 & 30.8 & 33.4 & 64.1 \\
\hline & MeanX $X_{m}$ & 13.0 & 53.8 & 2.4 & 220. & 1.1 & 19.8 & 19.9 & 43.6 & 64.1 \\
\hline & $\mathrm{CC}$ & 0.83 & 0.70 & 0.36 & 0.22 & 0.25 & 0.45 & 0.18 & 0.31 & 0.24 \\
\hline & $\operatorname{ANB}(\%)$ & -1.8 & 2.3 & 37.3 & 1.1 & -1.1 & 65.6 & -35 & 30.6 & 0.06 \\
\hline \multirow{4}{*}{ Weekday } & MeanX $_{o}$ & 17.1 & 44.3 & 2.1 & 189. & 1.3 & 31.9 & 32.4 & 36.1 & 68.4 \\
\hline & MeanX $X_{m}$ & 16.6 & 41.8 & 2.7 & 190. & 1.2 & 34.1 & 22.9 & 37.1 & 61.2 \\
\hline & $\mathrm{CC}$ & 0.94 & 0.81 & 0.58 & 0.33 & 0.54 & 0.78 & 0.48 & 0.43 & 0.53 \\
\hline & $\operatorname{ANB}(\%)$ & -2.7 & -5.6 & 28.2 & 0.37 & -7.5 & 7.0 & -29 . & 2.9 & -10 . \\
\hline \multirow{4}{*}{ Weekend } & MeanX $_{o}$ & 16.9 & 43.0 & 2.0 & 177. & 1.2 & 32.3 & 26.3 & 33.7 & 59.9 \\
\hline & MeanX $X_{m}$ & 16.2 & 41.1 & 2.6 & 193. & 1.1 & 34.7 & 19.8 & 33.8 & 54.7 \\
\hline & $\mathrm{CC}$ & 0.94 & 0.85 & 0.62 & 0.33 & 0.39 & 0.74 & 0.36 & 0.42 & 0.44 \\
\hline & $\operatorname{ANB}(\%)$ & -4.3 & -4.3 & 26.5 & 9.0 & -10 & 7.2 & -25 & 0.18 & -8.7 \\
\hline
\end{tabular}

\footnotetext{
${ }^{\mathrm{a}}$ MeanX $\mathrm{X}_{o}$ and $\mathrm{MeanX} \mathrm{X}_{m}$ refer to the mean value of the observations and model simulations; ${ }^{\mathrm{b}} \mathrm{CC}$ refers to the correlation coefficient and ANB the average normalized bias (\%) with a positive bias indicating a model overestimate; ${ }^{\mathrm{c}} \mathrm{T}, \mathrm{RH}, \mathrm{WS}$ and WD refer to temperature $\left({ }^{\circ} \mathrm{C}\right)$, relative humidity $(\%)$, wind speed $\left(\mathrm{m} \mathrm{s}^{-1}\right.$ ) and wind direction (degree) at reference heights; ${ }^{\mathrm{d}}$ The unit for chemical species is ppbv except for $\mathrm{CO}$ which is ppmv; and ${ }^{\mathrm{e}}$ Measured $\mathrm{NO}_{\mathrm{x}}$ is compared with the sum of modeled species corresponding to $\mathrm{NO}_{\mathrm{y}}$.
}

correlation coefficient during daytime is consistently larger than at nighttime for all variables considered. This will be examined further in Sect. 5.3.

\subsection{Performance statistics for weekday and weekend}

The model performance is both comparable and consistent for both weekdays and weekends in terms of meteorological variables (Table 1). The correlation coefficients during weekdays (weekends) are $0.94(0.94), 0.81(0.85), 0.58$ (0.62) and 0.33 ( 0.33 ) for temperature, relative humidity, wind speed and wind direction, respectively. The ANBs are also similar between weekdays and weekends for temperature, relative humidity and wind speed. For chemical species, the differences in mean values between the simulations and the observations are smaller with generally lower biases for weekends than for weekdays, suggesting that the respective $15 \%$, $25 \%$ and $10 \%$ reductions of the total emissions rates used for Saturday, Sunday and holidays are reasonable. Decreased correlation coefficients for $\mathrm{CO}, \mathrm{NO}$, and $\mathrm{NO}_{\mathrm{x}}$ are noted for weekends when compared to weekdays. This may indicate large uncertainties in the temporal distributions of the emissions rates for weekends as compared to weekdays. Table 1 also shows that the mean values of major pollutants (CO, NO, $\mathrm{NO}_{2}$ and $\mathrm{NO}_{\mathrm{x}}$ ) decrease from weekday to weekend both in observations and in simulations as expected.

For $\mathrm{O}_{3}$, Table 1 shows a slight increase from weekday (31.9 ppbv) to weekend (32.3 ppbv) in the observed means and the increased value is within the uncertainty of measurement (3\% according to Molina and Molina, 2002). At individual stations (not shown), the observed $\mathrm{O}_{3}$ shows small increases from weekday to weekend mainly at the central and northern part of the MCMA with small decreases elsewhere. This appears to be consistent with the findings of Stephen et al. (2008) who showed that afternoon $\mathrm{O}_{3}$ concentrations change minimally between workdays (Monday-Friday) and weekends and are occasionally higher on weekends.

Appreciable increases in correlation coefficients are noted for most of the VOC species for weekends when compared to weekdays (Table 2). This is in contrast to the decreased correlation coefficients for $\mathrm{CO}, \mathrm{NO}$, and $\mathrm{NO}_{\mathrm{x}}$ during the same time period (Table 1). The exact reason for this is unknown. Table 2 also indicates slight increases in the means for propene, $\mathrm{C} 4$-alkenes, isoprene and benzene during weekends when compared to weekdays with slight decreases for the other VOC species. 
(a) Planetary Boundary Layer Height (m) at 0000 LST

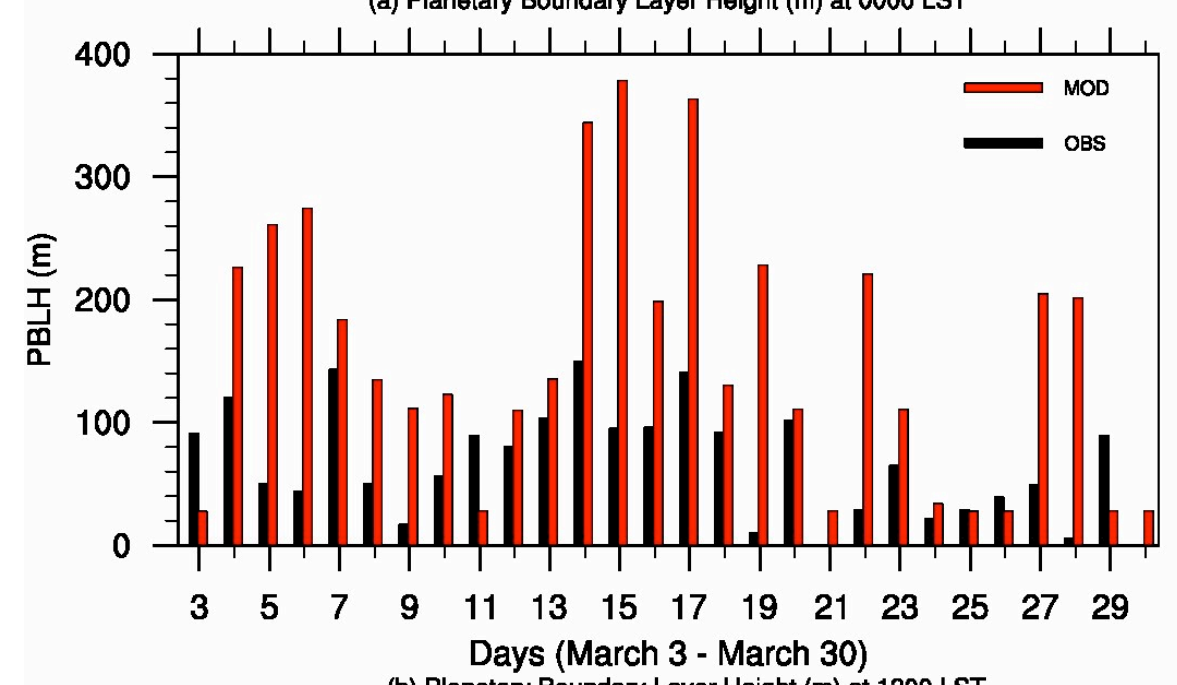

(b) Planetary Boundary Layer Height (m) at 1200 LST

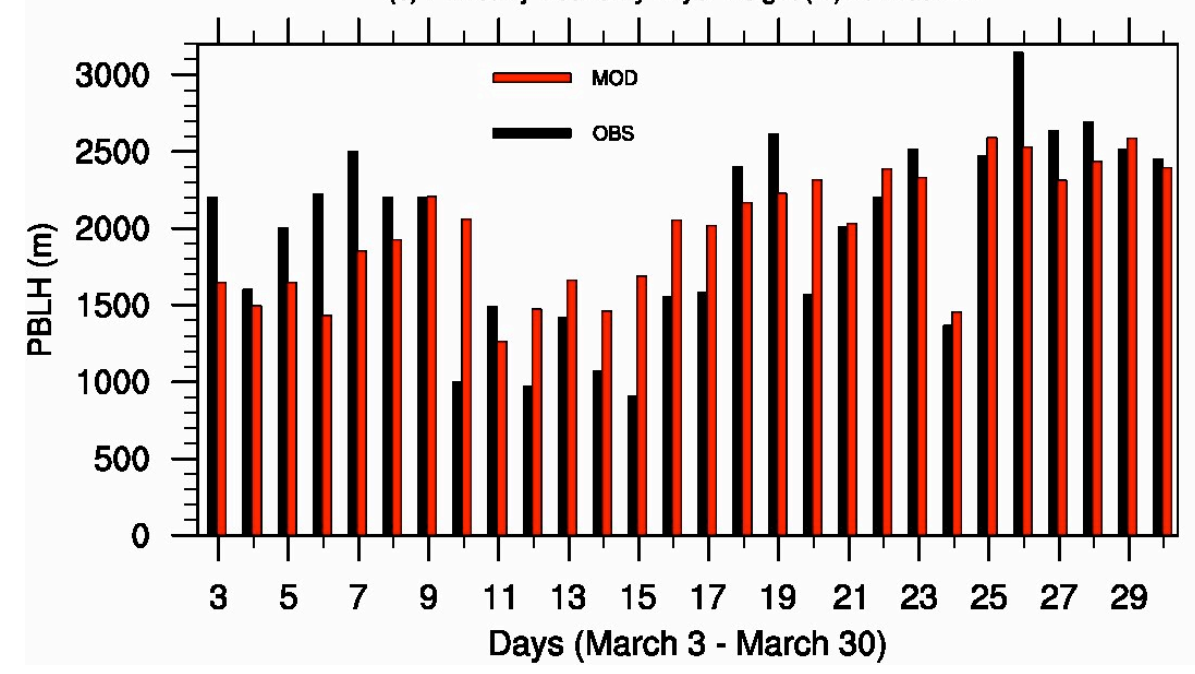

Fig. 4. Measurement determined and WRF/Chem simulated planetary boundary layer (PBL) height (m) at the headquarters of the Mexican National Weather Service valid at (a) 00:00 LST and (b) 12:00 LST during MILAGRO. OBS and MOD refer to measurements and model simulations, respectively.

\subsection{Effects of PBL and LSM parameterizations on me- teorology and chemistry}

Analyses in Sect. 5.1 show that the model performs better during daytime than nighttime not only for meteorological variables but also for chemical species. Nighttime chemical concentrations are primarily dictated by dynamical processes since photochemistry is largely inactive. As speculated above, a possible explanation of the differences in model performance between daytime and nighttime is the accuracy of the model simulated PBL and transport. The accuracy of the predicted PBL height is critical not only for realistically resolving the energy and moisture budgets within the boundary layer but also for accurate predictions of the transport and dispersion of chemical species.

\subsubsection{Measured and Modeled Daytime and Nighttime PBL Height}

Radiosonde observations have been carried out at the headquarters of the Mexican National Weather Service (GSM, $\left.19.404^{\circ} \mathrm{N}, 99.197^{\circ} \mathrm{W}\right)$ twice daily (06:00 and 18:00 LST) since 1999 and four times daily (00:00, 06:00, 12:00, and 18:00 LST) during MILAGRO. We employ the Modified Heffter technique (Snyder and Strawbridge, 2004) to determine the PBL height from the radiosonde measurements. This technique involves diagnosing a critical stable layer (CSL) that marks the top of the mixing layer. It is defined as the lowest layer that meets the following two criteria: $\Delta \theta / \Delta \mathrm{z}>0.001 \mathrm{~K} \mathrm{~m}^{-1}$ and $\theta_{t}-\theta_{b}>2 \mathrm{~K}$ where $\Delta \theta / \Delta \mathrm{z}$ is the potential temperature lapse rate; $\theta_{t}$ and $\theta_{b}$ represent 
Table 2. Performance statistics for predictions of VOC species.

\begin{tabular}{|c|c|c|c|c|c|c|c|c|c|c|c|}
\hline & & V1 & $\mathrm{V} 2$ & V3 & V4 & V5 & V6 & V7 & V8 & V9 & V10 \\
\hline \multirow{4}{*}{ All } & MeanX $_{o}^{a}$ & 38.9 & 6.0 & 17.6 & 11.7 & 0.64 & 4.3 & 1.6 & 12.1 & 3.8 & 1.1 \\
\hline & MeanX $_{m}^{a}$ & 17.9 & 5.5 & 16.1 & 14.1 & 0.57 & 2.3 & 1.1 & 10.5 & 3.4 & 2.6 \\
\hline & $C C^{b}$ & 0.26 & 0.52 & 0.41 & 0.24 & 0.23 & 0.45 & 0.49 & 0.42 & 0.50 & 0.56 \\
\hline & $\operatorname{ANB}(\%)^{b}$ & -52 & -4 & -3 & 26. & -9 & -45 . & -33 & -9 & -7 & 147. \\
\hline \multirow{4}{*}{ Daytime } & MeanX $_{o}$ & 33.5 & 6.6 & 16.3 & 12.9 & 0.74 & 4.9 & 1.9 & 10.9 & 3.7 & 1.2 \\
\hline & MeanX $_{m}$ & 13.7 & 6.2 & 13.2 & 12.7 & 0.47 & 3.1 & 0.9 & 9.1 & 2.9 & 2.3 \\
\hline & $\mathrm{CC}$ & 0.66 & 0.63 & 0.69 & 0.36 & 0.46 & 0.51 & 0.66 & 0.74 & 0.76 & 0.75 \\
\hline & $\operatorname{ANB}(\%)$ & -57 & 2. & -12 & 4. & -33 & -32 & -51 & -13 & -17 & 103. \\
\hline \multirow{4}{*}{ Nighttime } & MeanX $X_{o}$ & 45.2 & 5.4 & 19.0 & 10.5 & 0.54 & 3.8 & 1.3 & 13.4 & 4.0 & 1.1 \\
\hline & MeanX $_{m}$ & 23.0 & 4.6 & 19.5 & 15.8 & 0.68 & 1.3 & 1.2 & 12.3 & 4.0 & 3.1 \\
\hline & $\mathrm{CC}$ & -0.2 & 0.07 & 0.01 & 0.07 & -0.2 & 0.16 & 0.13 & 0.06 & -0.0 & 0.13 \\
\hline & $\operatorname{ANB}(\%)$ & -48 & -12 & 7. & 56. & 29. & -64 & -2 & -6 & 3. & 203. \\
\hline \multirow{4}{*}{ Weekday } & MeanX $X_{o}$ & 38.0 & 6.3 & 16.9 & 12.3 & 0.62 & 4.5 & 1.6 & 12.3 & 3.9 & 1.2 \\
\hline & MeanX $X_{m}$ & 19.0 & 5.7 & 17.0 & 14.8 & 0.60 & 2.3 & 1.1 & 11.1 & 3.6 & 2.8 \\
\hline & $\mathrm{CC}$ & 0.24 & 0.49 & 0.42 & 0.20 & 0.21 & 0.42 & 0.49 & 0.43 & 0.48 & 0.54 \\
\hline & $\mathrm{ANB}(\%)$ & -49 . & -5 & 3. & 23 & -3 & -45 & -29 & -9 & -8 & 144. \\
\hline \multirow{4}{*}{ Weekend } & MeanX $_{o}$ & 41.7 & 5.3 & 19.6 & 10.2 & 0.72 & 4.0 & 1.8 & 11.4 & 3.6 & 1.1 \\
\hline & MeanX $_{m}$ & 15.3 & 5.1 & 13.8 & 12.4 & 0.48 & 2.1 & 0.9 & 9.2 & 3.0 & 2.3 \\
\hline & $\mathrm{CC}$ & 0.36 & 0.66 & 0.41 & 0.39 & 0.31 & 0.62 & 0.57 & 0.45 & 0.60 & 0.67 \\
\hline & $\operatorname{ANB}(\%)$ & -60 . & 1. & -17 & 33. & -24 & -43 & -42 & -11 & -6 & 156. \\
\hline
\end{tabular}

Subscripts ${ }^{\mathrm{ab}}$ are the same as in Table 1. VOC species are represented by V1 to V10. V1: propene; V2: acetaldehyde; V3: c4-alkenes; V4: acetone and propanal; V5: isoprene; V6: methylethyl ketone, butanal and methylglyoxal; V7: benzene; V8: toluene; V9: c9-aromatics; and V10: c10-aromatics.

the potential temperatures at the top and bottom of the stable layer, respectively. We have tested this technique in Mexico City and it works reasonably well for unstable PBL at 12:00 LST. By 06:00 LST, the atmosphere is transitioning from nighttime stable condition to daytime unstable condition and this technique exhibits large uncertainties in determining the PBL height whereas the opposite transition occurs by 18:00 LST (see also Snyder and Strawbridge, 2004). We compare the model simulated PBL height with that determined from the radiosonde measurements at 00:00 and 12:00 LST. For nighttime (00:00 LST) PBL height, we define it as the height of the inversion layer or the low-level jet if present; whichever is lower.

The observed and simulated PBL heights are shown in Fig. 4 for 00:00 LST and 12:00 LST. The model resolves the PBL height at 12:00 LST reasonably well in terms of magnitude and temporal variations as compared to rawinsonde measurements (Fig. 4b). The correlation coefficient between the measurements and simulations is 0.66. The simulated PBL height also compares favorably with rawinsonde, lidar and profiler measurements reported in Shaw et al. (2007). At 00:00 LST the simulated PBL height matches the measurements to some extent (Fig. 4a); the simulated PBL height varies between 20 and $350 \mathrm{~m}$ while the PBL height observed by rawinsonde ranges from 0 to $150 \mathrm{~m}$ (Fig. 4a). This is an improvement over the previous version of YSU PBL scheme that simulates flat and low PBL height $(\sim 28 \mathrm{~m})$ all night long (not shown). The correlation coefficient between the measurements and simulations at 00:00 LST is 0.40.

\subsubsection{Sensitivity Study Using Combinations of PBL and LSM parameterizations}

It has been recognized that sensitivities and uncertainties in air quality modeling arise when meteorological fields are generated using different parameterizations, as well as spatial and temporal resolutions (Alapaty et al., 1995; Pielke and Uliasz, 1998; Seaman, 2000). In this section, sensitivity studies are performed using different PBL and LSM schemes to see if there is a preferred combination in reproducing the observations. The model runs above were carried out using the YSU PBL scheme and the NOAH LSM for the entire period of MILAGRO. As we will see later, different PBL schemes and LSMs affect not only the simulated PBL height but also wind speed, which affect the mixing and transport of pollutants. In the following, we examine the model performance in resolving dynamic processes and chemical concentrations using various combinations of PBL schemes and LSMs: YSUNOAH, YSURUC, MYJNOAH and MYJRUC. 

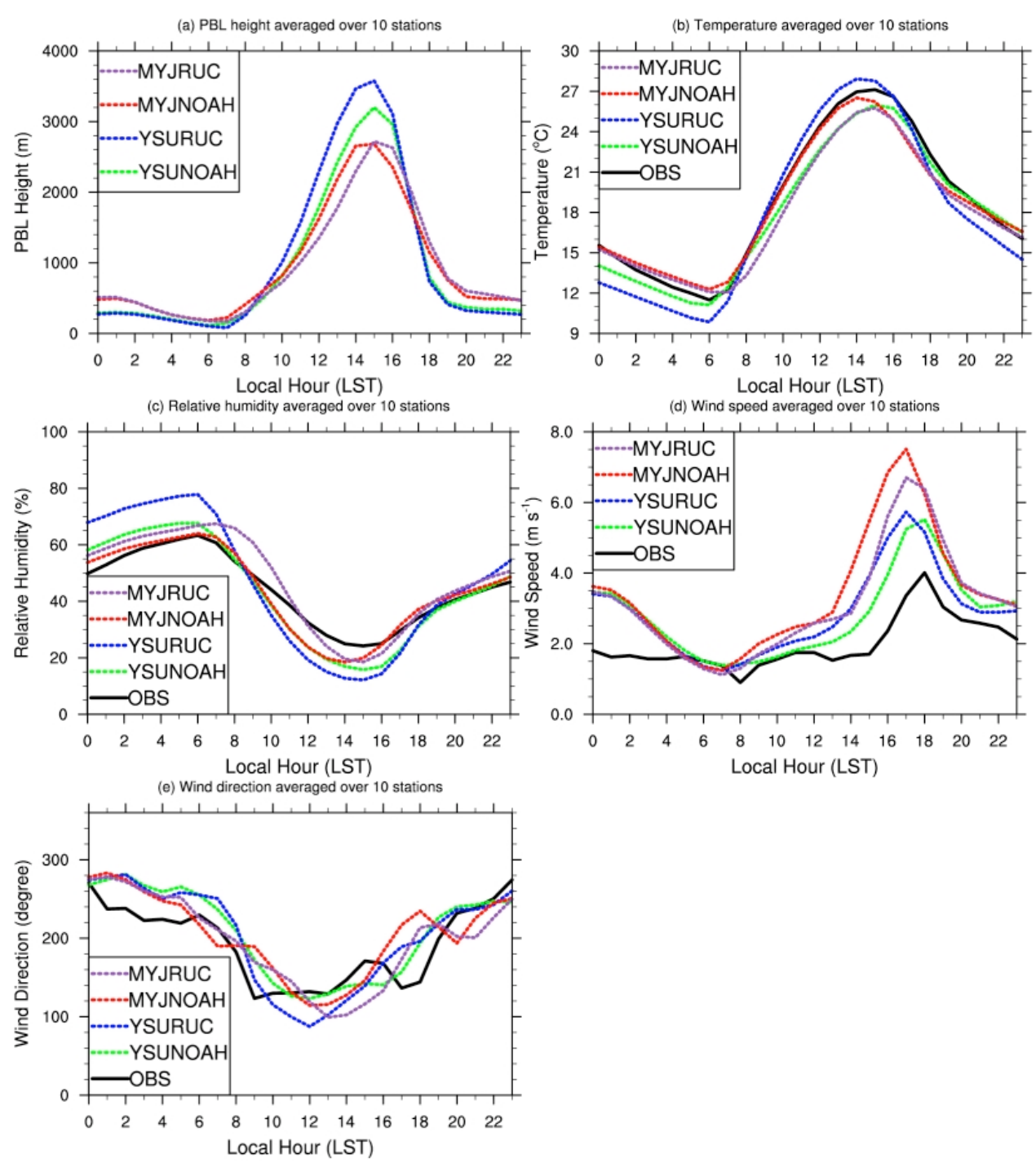

Fig. 5. Simulated (a) PBL height (m), (b) surface temperature $\left({ }^{\circ} \mathrm{C}\right)$, (c) surface relative humidity, (d) surface wind speed (m $\left.\mathrm{s}^{-1}\right)$, and (e) surface wind direction (degree) averaged over 10 monitoring stations and over 13-17 March 2006 using combinations of YSU and MYJ planetary boundary layer schemes and NOAH and RUC land surface models. Observations are also shown for temperature, relative humidity, wind speed and wind direction.

Figure 5 shows the simulated meteorological variables (surface temperature, relative humidity, wind speed and direction) as well as PBL height averaged over the 10 monitoring stations and over a 5-day period (13-17 March) and compared with available observations. The simulated peak PBL height during daytime using the YSU scheme is $500-1000 \mathrm{~m}$ higher than the MYJ scheme (Fig. 5a). Among the four combinations, YSURUC produces the highest PBL height of $3800 \mathrm{~m}$. During nighttime, the YSU (MYJ) scheme simulates variable PBL height ranging from 20 to $300 \mathrm{~m}$ (200 to $500 \mathrm{~m}$ ). Figure 5a also shows that the mixing layer simulated by the YSU scheme collapses faster between 16:00 and 18:00 LST than by the MYJ scheme.
There are mixed results in terms of surface temperature when compared to the observations (Fig. 5b). YSURUC appears to best capture the observed daytime temperature among all the combinations but it does the poorest in resolving the observed nighttime temperature. On the other hand, MYJNOAH and MYJRUC simulate the observed temperature better in nighttime than in daytime. Daytime cold biases are evident with MYJNOAH, MYJRUC and YSUNOAH. For YSUNOAH, the simulated maximum temperature also occurs about one hour later than the observations. All combinations show mainly wet biases in surface relative humidity during nighttime and dry biases during daytime (Fig. 5c). The largest biases in relative humidity are associated with YSURUC. 

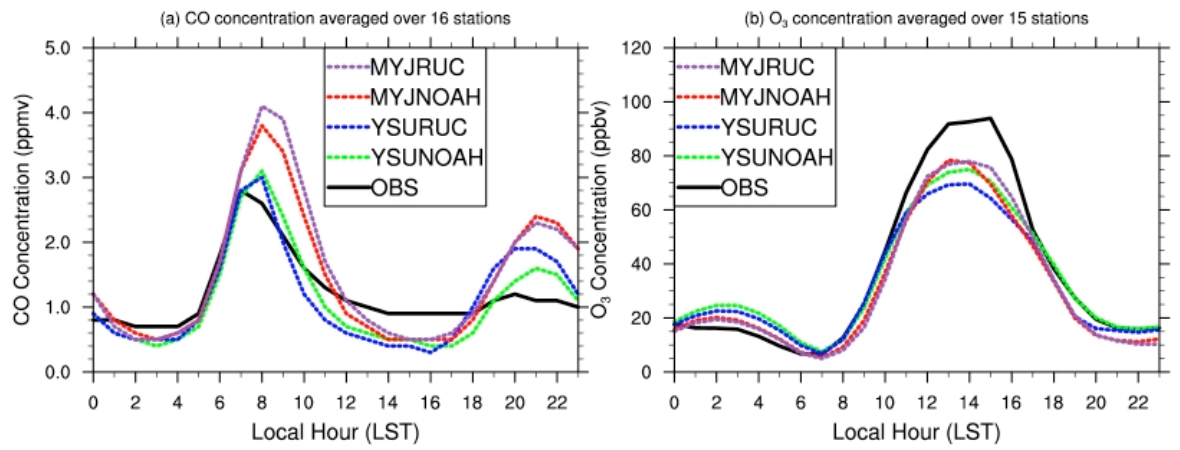

Fig. 6. Observed and simulated (a) CO concentration (ppmv) averaged over 16 monitoring stations, and (b) $\mathrm{O}_{3}$ concentration (ppbv) averaged over 15 monitoring stations and over 13-17 March 2006 using combinations of YSU and MYJ planetary boundary layer schemes and NOAH and RUC land surface models.

Model overestimation of the observed daytime surface wind speed is noted for all combinations (Fig. 5d) with the largest overestimation being associated with the MYJ PBL scheme (MYJNOAH and MYJRUC). Between 19:00 and 23:00 LST, the simulated wind speed exhibits a gentle drop for the YSU scheme in contrast to a sharp drop for the MYJ scheme (Fig. 5d). In terms of surface wind direction (Fig. 5e), a reasonably good agreement is noted between the simulations and the observations for all combinations.

The observed $\mathrm{CO}$ peak concentrations during early morning hours are overestimated using the MYJ scheme (Fig. 6a). Figure 5a shows that the PBL height during the same time period increases more slowly with the MYJ scheme than with the YSU scheme, suggesting that the pollutants may be trapped longer with the MYJ scheme. During daytime, the observed $\mathrm{CO}$ concentrations are underestimated using all combinations. This is probably related to the overestimation of daytime surface wind speed by all combinations (see Fig. 5d). Between 19:00 and 23:00 LST, the simulated CO concentration is larger for the MYJ scheme than for the YSU scheme when compared to observations (Fig. 6a). This is probably due to the sharp drop of surface wind speed for the same time period when using the MYJ scheme (see Fig. 5d), since a sudden decrease in wind speed would help to trap the pollutants within the boundary layer. In contrast, during the same time period the simulated $\mathrm{CO}$ concentrations using the YSU scheme are lower and closer to the observations than using the MYJ scheme, which is mainly attributed to the simulated higher surface wind speed. Both the observed and the simulated $\mathrm{NO}_{\mathrm{y}}$ concentrations exhibit similar distributions to CO (not shown). All combinations underestimate the observed $\mathrm{O}_{3}$ concentrations during daytime (Fig. 6b), most likely related to the overestimation of the daytime surface wind speed.

Similar analyses were also performed at individual stations (not shown), and yielded results similar to the mean pattern shown in Figs. 5 and 6. The model performance in terms of meteorological parameters and chemical species during different time of the day varies by PBL and LSM schemes, but no combinations are the best in reproducing meteorological fields and chemical observations. This is because chemical species are sensitive not only to PBL height but also to surface wind speed, which are affected by both PBL and LSM schemes. Mao et al. (2005) performed sensitivity studies of MM5-CMAQ (Community Multiscale Air Quality) modeling system to a range of available PBL schemes by comparing model output against observations from meteorological and air quality monitoring networks. They also noted that on an urban scale, no favorable PBL scheme was identified in reproducing the observations. Our analyses further show that the PBL schemes are the primary drivers for modeled meteorological variables and chemical species at surface since same PBL scheme with different LSMs produces largely similar results while same LSM with different PBL schemes produces quite different results.

\subsection{Weather episodes}

de Foy et al. (2005) identified three major episode types during MCMA-2003 based on the wind circulation patterns and the $\mathrm{O}_{3}$ peak location: $\mathrm{O}_{3}$-South, $\mathrm{O}_{3}$-North and Cold Surge. $\mathrm{O}_{3}$-South days are characterized by weak synoptic forcing over central Mexico due to a high-pressure system. Strong solar heating leads to pronounced local circulations with upslope flow during afternoon that give way to downslope flow in the evening and early morning. Peak $\mathrm{O}_{3}$ concentrations occur in the south of the MCMA. $\mathrm{O}_{3}$-North days occur when a deep low-pressure system penetrates southward over the western United States. Mexico City is located in the flank of the low-pressure system with close proximity to the subtropical jet. Strong southwesterlies through a deep layer result in $\mathrm{O}_{3}$ peaks in the north of the MCMA. Cold Surge days are related to "El Norte" events (Schultz et al., 1998) with strong low-level northerly flows to the north of Mexico City associated with the passage of cold fronts over the Gulf of Mexico. 

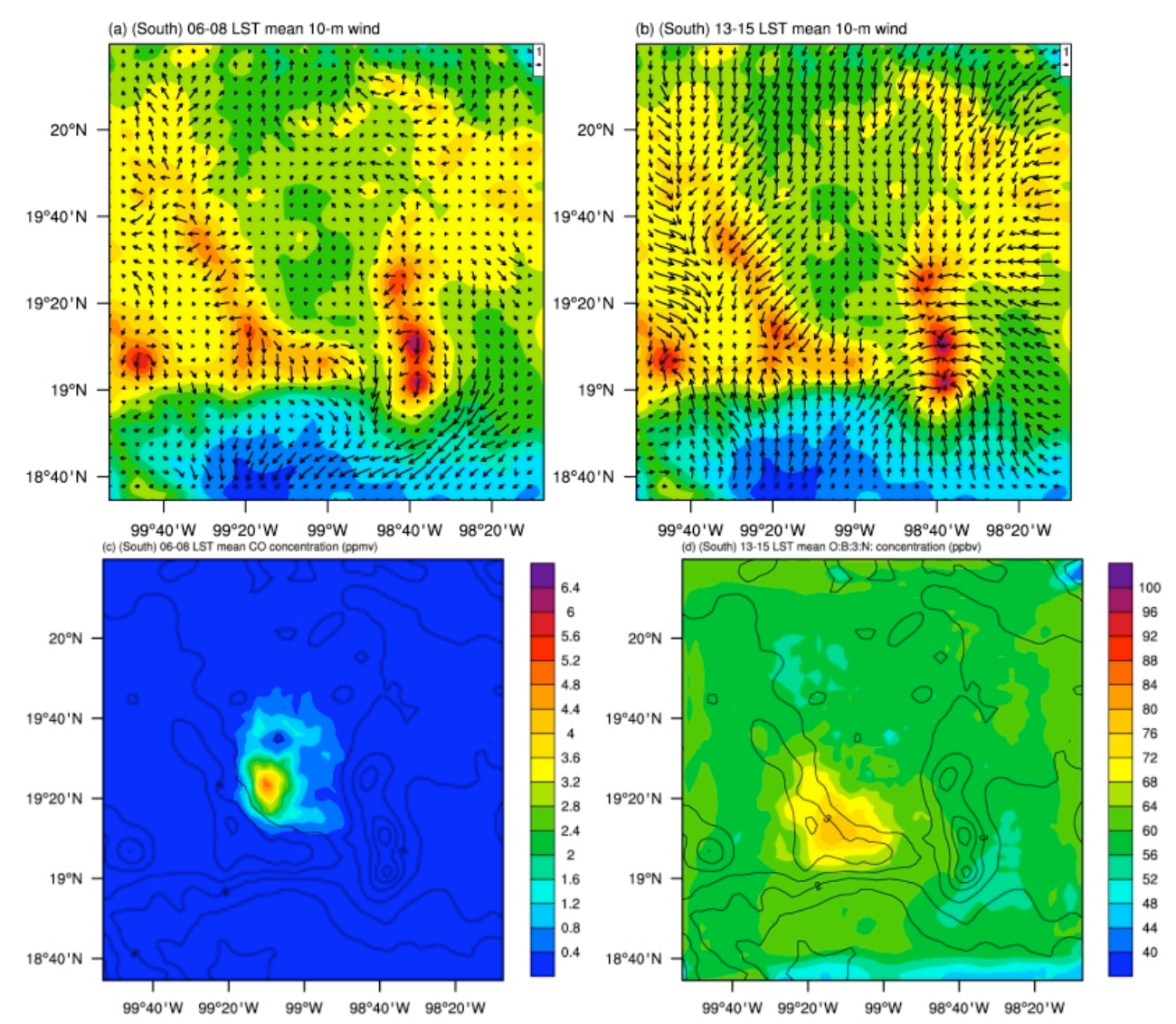

Fig. 7. Model simulated (a) morning (06:00-08:00 LST averaged) surface wind ( $\mathrm{m} \mathrm{s}^{-1}$ ), (b) afternoon (13:00-15:00 LST averaged) surface wind $\left(\mathrm{m} \mathrm{s}^{-1}\right)$, (c) morning (06:00-08:00 LST averaged) CO concentration (ppmv), and (d) afternoon (13:00-15:00 LST averaged) $\mathrm{O}_{3}$ concentration (ppbv) for the $\mathrm{O}_{3}$-South episode (6 March through 8). Color shading in (a) and (b) denotes the topography.

Peak $\mathrm{O}_{3}$ concentrations are located in the city center. These three major episode types are also identified during MCMA2006 (de Foy et al., 2008).

Fast et al. (2007) presented detailed descriptions of the meteorological conditions during the MILAGRO field campaign. They identified three El Norte events during MILAGRO: 14-15 March as Norte 1, 21 March as Norte 2, and 23-25 March as Norte 3. We extensively examined the daily synoptic conditions at low level $(850 \mathrm{mb})$ and middle level $(500 \mathrm{mb})$ based on the NCEP Final Analysis data and the daily mesoscale conditions based on the WRF/Chem simulations during 3-30 March 2006. We identify the following $\mathrm{O}_{3}$-South episodes: 3-8 March, 12-13 March, 16-17 March, and 26-28 March; and $\mathrm{O}_{3}$-North episodes: 9-11 March, 1820 March, 22 March, and 29-30 March. In this section, the WRF/Chem simulations will be examined for one $\mathrm{O}_{3}$-South episode, 6-8 March, one $\mathrm{O}_{3}$-North episode, 19-20 March, and the Norte 3 event, 23-25 March. The main purpose of this section is to evaluate the performance of WRF/Chem under different weather regimes.

\subsection{1 $\mathrm{O}_{3}$-South episode}

Figures $7 \mathrm{a}$ and $\mathrm{b}$ show the morning (06:00-08:00 LST averaged) and afternoon (13:00-15:00 LST averaged) surface wind flow for the $\mathrm{O}_{3}$-South episode (6 March through 8). Notable features are the prevailing downslope flow in the morning and upslope flow in the afternoon. The morning downslope flow is generally weaker than the afternoon upslope flow. Weak winds are also evident in the central Mexico basin for both time periods. These wind patterns agree with the depiction for $\mathrm{O}_{3}$-South episode in de Foy et al. (2005). In association with these wind patterns, peak $\mathrm{CO}$ concentrations in the morning are located near the center of the MCMA (Fig. 7c) while peak $\mathrm{O}_{3}$ concentrations in the afternoon are situated along the slopes in the south and southwest of the MCMA (Fig. 7d).

Figure 8 shows the observed and model simulated meteorological variables at surface averaged hourly over the 10 monitoring stations for the period of 00:00 LST 6 March through 23:00 LST 8 March. The observed temperature lies between $8^{\circ} \mathrm{C}$ and $26^{\circ} \mathrm{C}$ with relative humidity ranging from $20 \%$ to $40 \%$ (Fig. $8 \mathrm{a}, \mathrm{b}$ ). The model captures the diurnal 

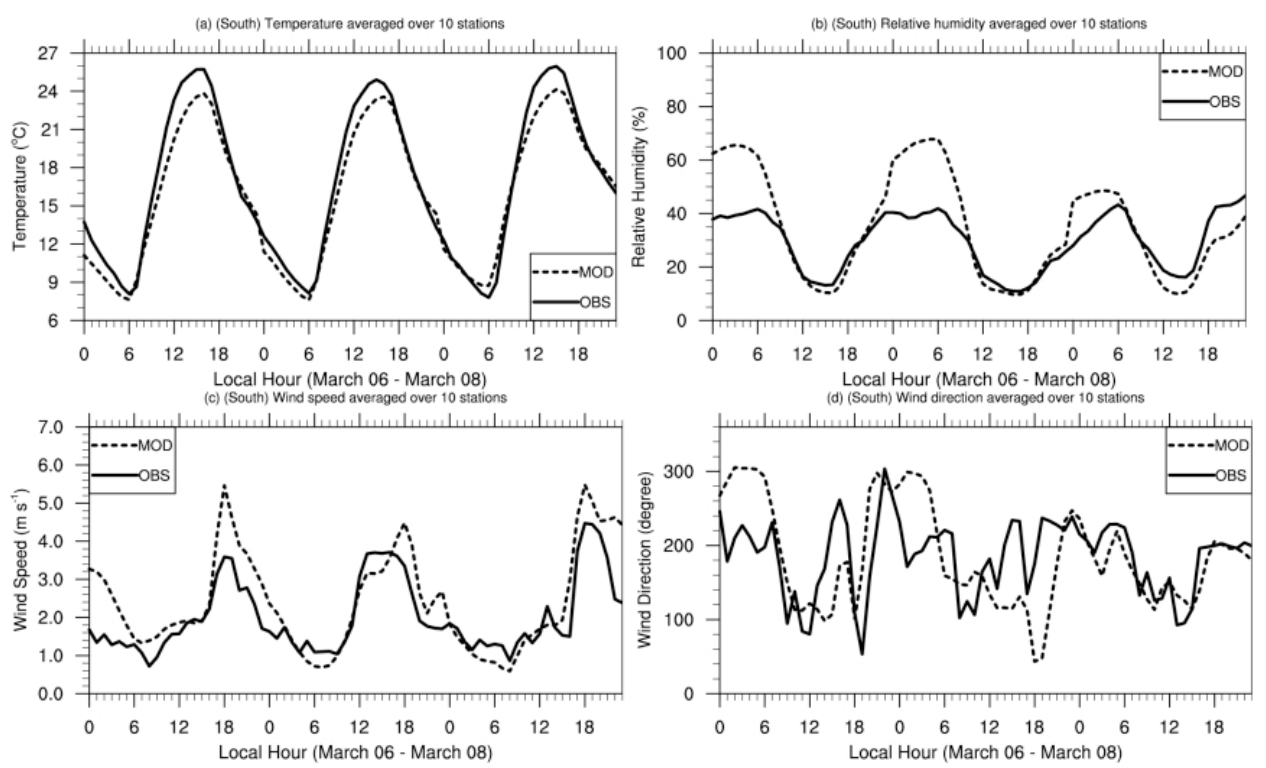

Fig. 8. Observed and model simulated (a) surface temperature $\left({ }^{\circ} \mathrm{C}\right),(\mathbf{b})$ surface relative humidity $(\%)$, (c) surface wind speed (m $\left.\mathrm{s}^{-1}\right)$, and (d) surface wind direction (degree) averaged over the 10 monitoring stations for the period of 00:00 LST 6 March through 23:00 LST 8 March (the $\mathrm{O}_{3}$-South episode).
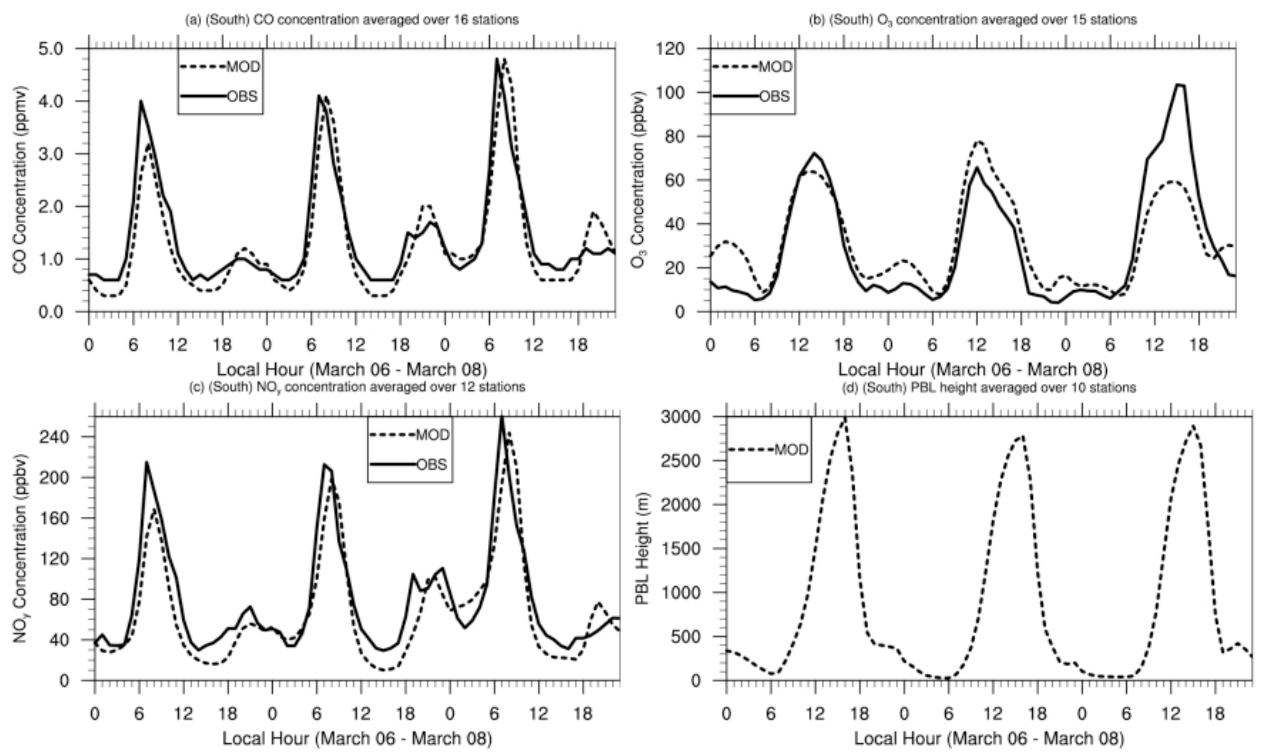

Fig. 9. Observed and model simulated (a) CO concentration (ppmv), (b) $\mathrm{O}_{3}$ concentration (ppbv) and (c) $\mathrm{NO}_{\mathrm{y}}$ concentration (ppbv) averaged over the monitoring stations that reported valid measurements for the period of 00:00 LST 6 March through 23:00 LST 8 March (the $\mathrm{O}_{3}$-South episode). The simulated PBL height for the same time period is shown in (d).

cycle of the observed temperature and relative humidity but underestimates daytime maximum temperatures by $2-3^{\circ} \mathrm{C}$ and overestimates nighttime relative humidity by $10-20 \%$. The observed winds are weak $\left(\leq 3 \mathrm{~m} \mathrm{~s}^{-1}\right)$ with wind directions shifting from nocturnal downslope flow to afternoon upslope flow throughout the diurnal cycle (Fig. 8c, d). The model reproduces the observed wind speed and wind direction reasonably well for this weather episode.

Figure 9 shows the observed and model simulated $\mathrm{CO}$, $\mathrm{O}_{3}$ and $\mathrm{NO}_{\mathrm{y}}$ concentrations as well as the model simulated PBL height for the same time period as in Fig. 8. The simulated PBL height ranges from $20 \mathrm{~m}$ to $2500 \mathrm{~m}$ and peaks 

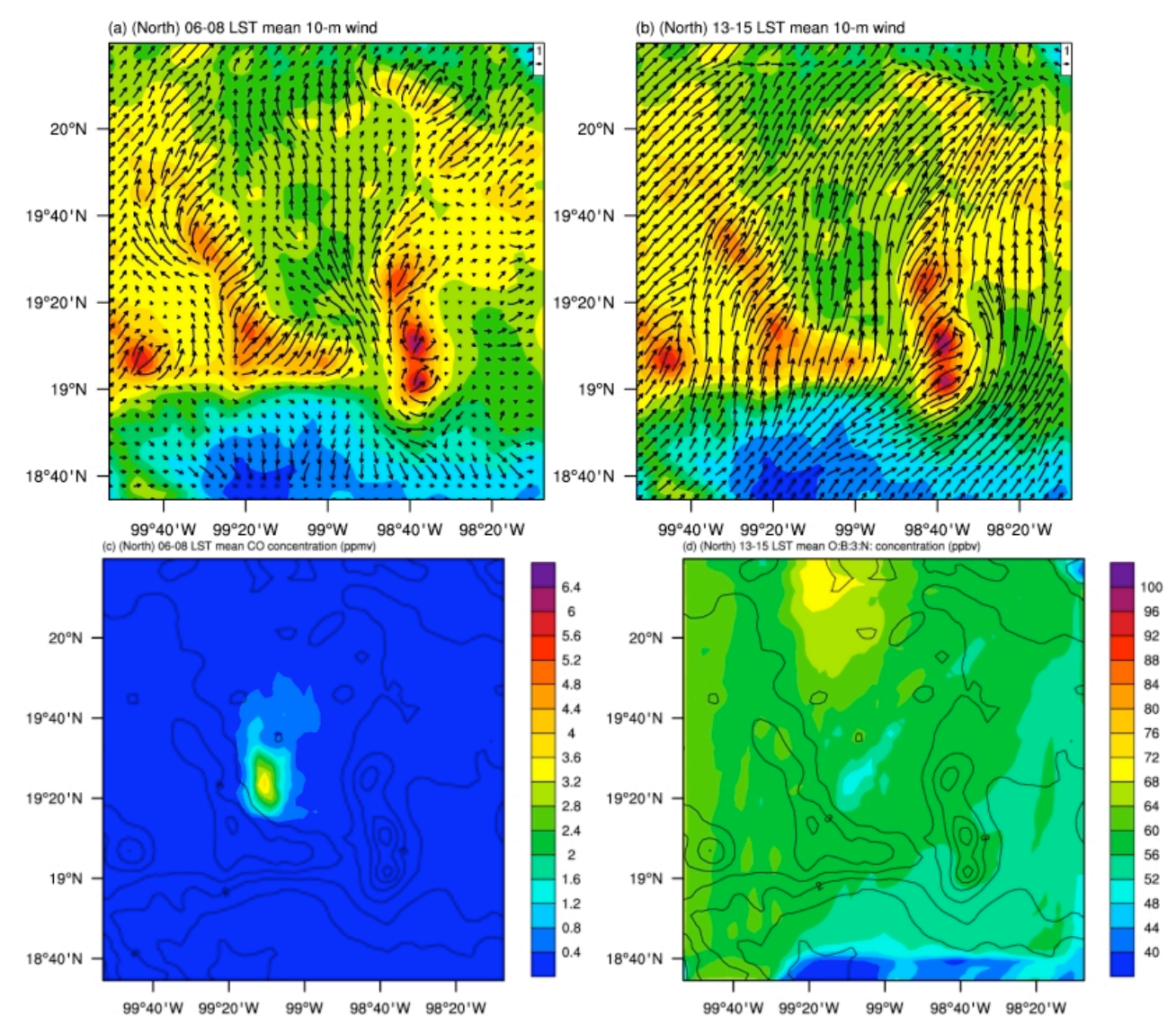

Fig. 10. Same as Fig. 7 except for the $\mathrm{O}_{3}$-North episode (19 March through 20).

at 15:00 LST (Fig. 9d). This peak height appears to be $300-500 \mathrm{~m}$ lower than that determined from wind profiler measurements at T0 supersite located in central Mexico City (Shaw et al., 2007). The observed peak $\mathrm{CO}$ and $\mathrm{O}_{3}$ concentrations on 6 and 7 March are about 4 ppmv and 70 ppbv, respectively (Fig. 9a and b). On 8 March, these values jump to $4.5 \mathrm{ppmv}$ and $100 \mathrm{ppbv}$. Notice that the monitoring stations are situated mainly within the center of the city (Fig. 2). A slight shift in wind direction to more westerly as indicated in Fig. $8 \mathrm{~d}$ on 8 March appears to bring the pollution over the center of the city and hence the increase in the observed pollution concentrations at the monitoring stations. The model simulated $\mathrm{CO}$ and $\mathrm{O}_{3}$ concentrations generally agree with the observations although the model tends to overestimate nighttime $\mathrm{O}_{3}$ concentrations by $5-10 \mathrm{ppbv}$ on all three days and underestimate daytime peak $\mathrm{O}_{3}$ concentrations by $\sim 40 \mathrm{ppbv}$ on 8 March. Both the observed and simulated $\mathrm{NO}_{\mathrm{y}}$ exhibits similar distributions to those of $\mathrm{CO}$ (Fig. 9a and c).

\subsection{2 $\mathrm{O}_{3}$-North Episode}

Figures 10a and $\mathrm{b}$ show the morning and afternoon surface wind flow for the $\mathrm{O}_{3}$-North episode (19 March through 20).
Downslope flow with relatively strong southerly components is evident in the early morning (Fig. 10a). Strong $\left(>5 \mathrm{~m} \mathrm{~s}^{-1}\right.$ ) southerly and southwesterly winds prevail in the afternoon over the entire basin (Fig. 10b). This wind pattern helps to transport the Mexico City pollutants farther away from the sources and affects a larger area as indicated by the broad horizontal distribution of $\mathrm{O}_{3}$ concentrations that extends north of the MCMA (Fig. 10d). $\mathrm{O}_{3}$ peaks are located to the north of the city. For this weather episode, the maximum $\mathrm{CO}$ concentrations in the early morning are situated in the central and northern part of the city (Fig. 10c).

Comparisons of the model simulated meteorological variables and chemical species $\left(\mathrm{CO}, \mathrm{O}_{3}\right.$ and $\left.\mathrm{NO}_{\mathrm{y}}\right)$ with observations for the $\mathrm{O}_{3}$-North episode averaged over the monitoring stations are presented in Figs. 11 and 12, respectively. The observed temperature maxima increase slightly from 19 March to 20 March while the observed relative humidity maxima decrease during the same time period with relatively strong and persistent southerly winds (Fig. 11). The model simulations are largely consistent with the observations although model deficiencies such as cold biases are also noted (Fig. 11). The observed CO concentrations are rather low $(<2$ ppmv $)$ for this $\mathrm{O}_{3}$-North episode as the 

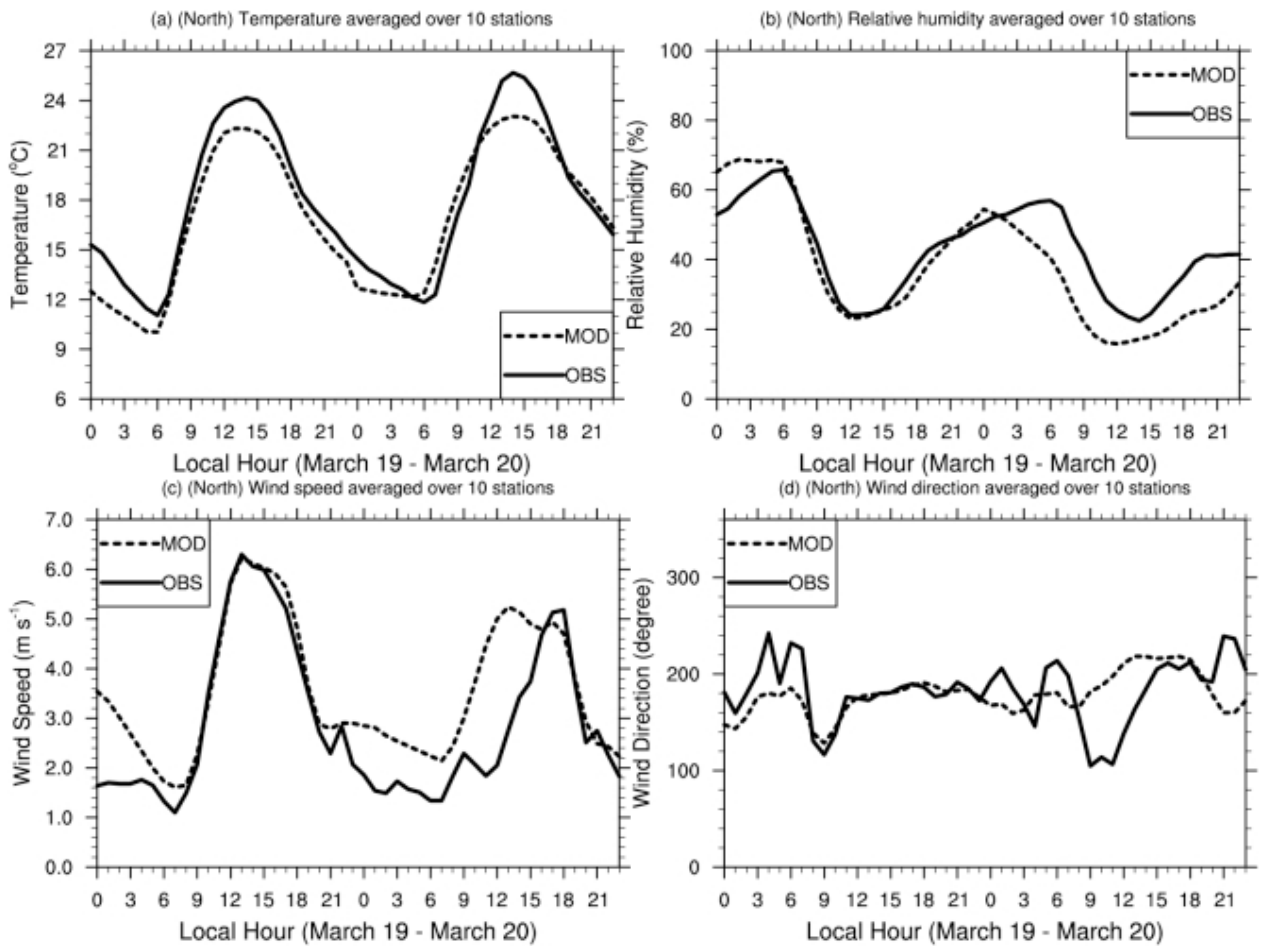

Fig. 11. Same as Fig. 8 except for the period of 00:00 LST 19 March through 23:00 LST 20 March (the $\mathrm{O}_{3}$-North episode).

pollutants are transported mainly to the north. The model resolves the observed temporal distributions in $\mathrm{CO}$ and $\mathrm{NO}_{\mathrm{y}}$ concentrations but tends to overestimate the maximum concentrations (Fig. 12a, c). The observed $\mathrm{O}_{3}$ concentrations are also low $(<65 \mathrm{ppbv})$ for this episode with a less well-defined diurnal cycle on 19 March (Fig. 12b). These features are reasonably well represented by the model although the model overestimates the daytime $\mathrm{O}_{3}$ concentrations on 19 March by $\sim 10$ ppbv (Fig. 12b). The simulated maximum PBL height for this weather episode is $2000 \mathrm{~m}$ on 19 March and $2300 \mathrm{~m}$ on 20 March (Fig. 12d) that appears to be underestimated as compared to Shaw et al. (2007) who show peak PBL height of $3000 \mathrm{~m}$ on 19 March and $3200 \mathrm{~m}$ on 20 March at T0. This underestimation of the simulated PBL peak height on 19 March may only partly explain the overestimation of the simulated daytime $\mathrm{O}_{3}$ concentrations, since the model does not overestimate $\mathrm{O}_{3}$ concentrations on 20 March even with underestimated peak PBL height.

\subsubsection{El Norte Episode}

Figure $13 \mathrm{a}$ and $\mathrm{b}$ show the morning and afternoon surface wind flow for the Norte 3 event (March 23 through 25). The morning wind pattern is characterized by weak downslope flow along the slopes and northerly winds to the northeast of the MCMA (Fig. 13a). In the afternoon (Fig. 13b), northerly winds to the north of the MCMA are accompa- nied by southerly winds to the south of the MCMA, creating a convergence zone over the city. In association with these flow patterns, maximum $\mathrm{CO}$ and $\mathrm{O}_{3}$ concentrations are located approximately in the center of the Mexico City (Fig. 13c, d). Note that for this Norte event, considerable $\mathrm{O}_{3}$ is also transported through the narrow gap to the south of the city, which is not seen for the other two weather episodes (cf. Figs. $7 \mathrm{~d}$ and $10 \mathrm{~d}$ ).

Comparisons of the model simulated meteorological variables and chemical species $\left(\mathrm{CO}, \mathrm{O}_{3}\right.$ and $\left.\mathrm{NO}_{\mathrm{y}}\right)$ with observations for the Norte 3 event are shown in Figs. 14 and 15, respectively. This event featured a gradual decrease in daytime temperature and wind speed and a gradual increase in relative humidity with large changes in wind direction from March 23 to March 25 (Fig. 14) as the cold-front system moved through. Appreciable rainfall was recorded at T0 on March 23 and March 25 (Fast et al., 2007; de Foy et al., 2008). There is generally a good agreement between the model simulations and the observations in terms of magnitude and temporal distribution (Fig. 14). Model discrepancies include daytime cold biases on 23 and 24 March as well as an underestimate of the peak wind speed on 24 March.

The observed CO concentrations on 24 and 25 March are low ( $\leq 1.5 \mathrm{ppmv})$ and do not display a pronounced diurnal cycle (Fig. 15a) due to the influence of the passing cold-front system (Fast et al., 2007). The model simulated CO concentrations compare favorably with the observations except 

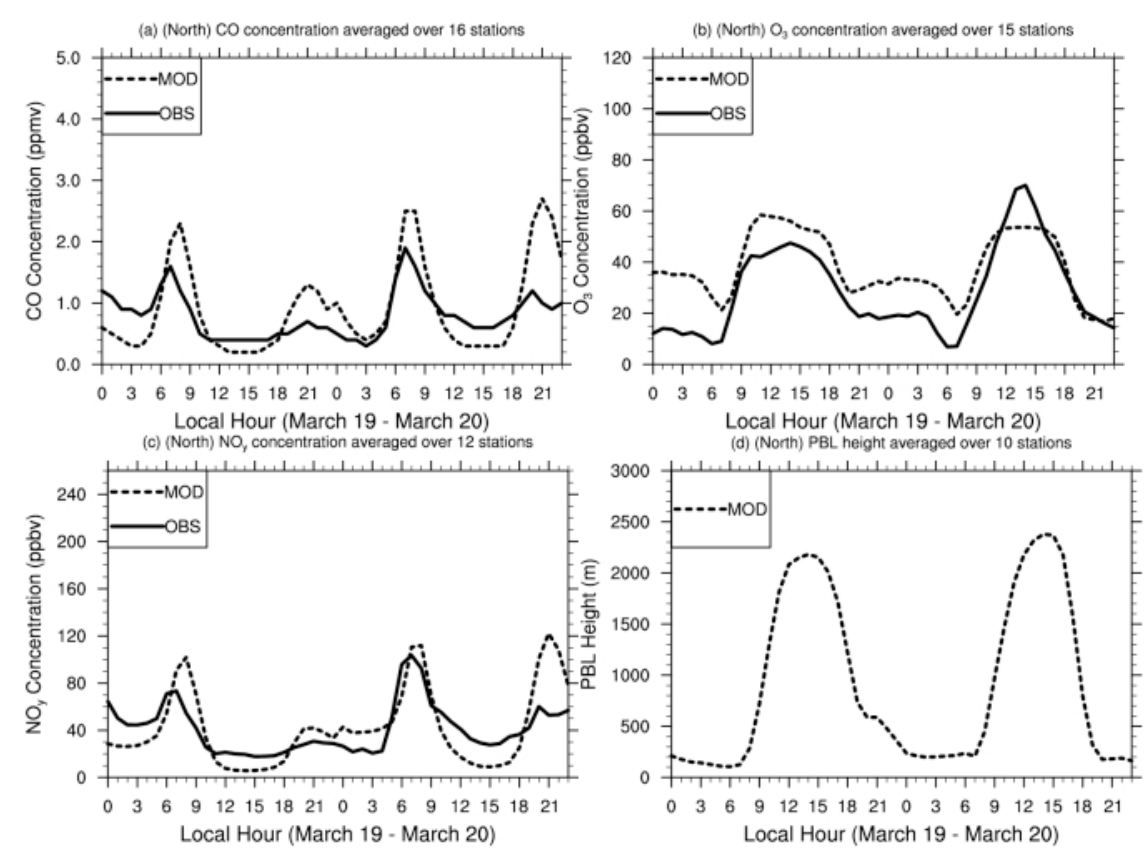

Fig. 12. Same as Fig. 9 except for the period of 00:00 LST 19 March through 23:00 LST 20 March (the $\mathrm{O}_{3}$-North episode).
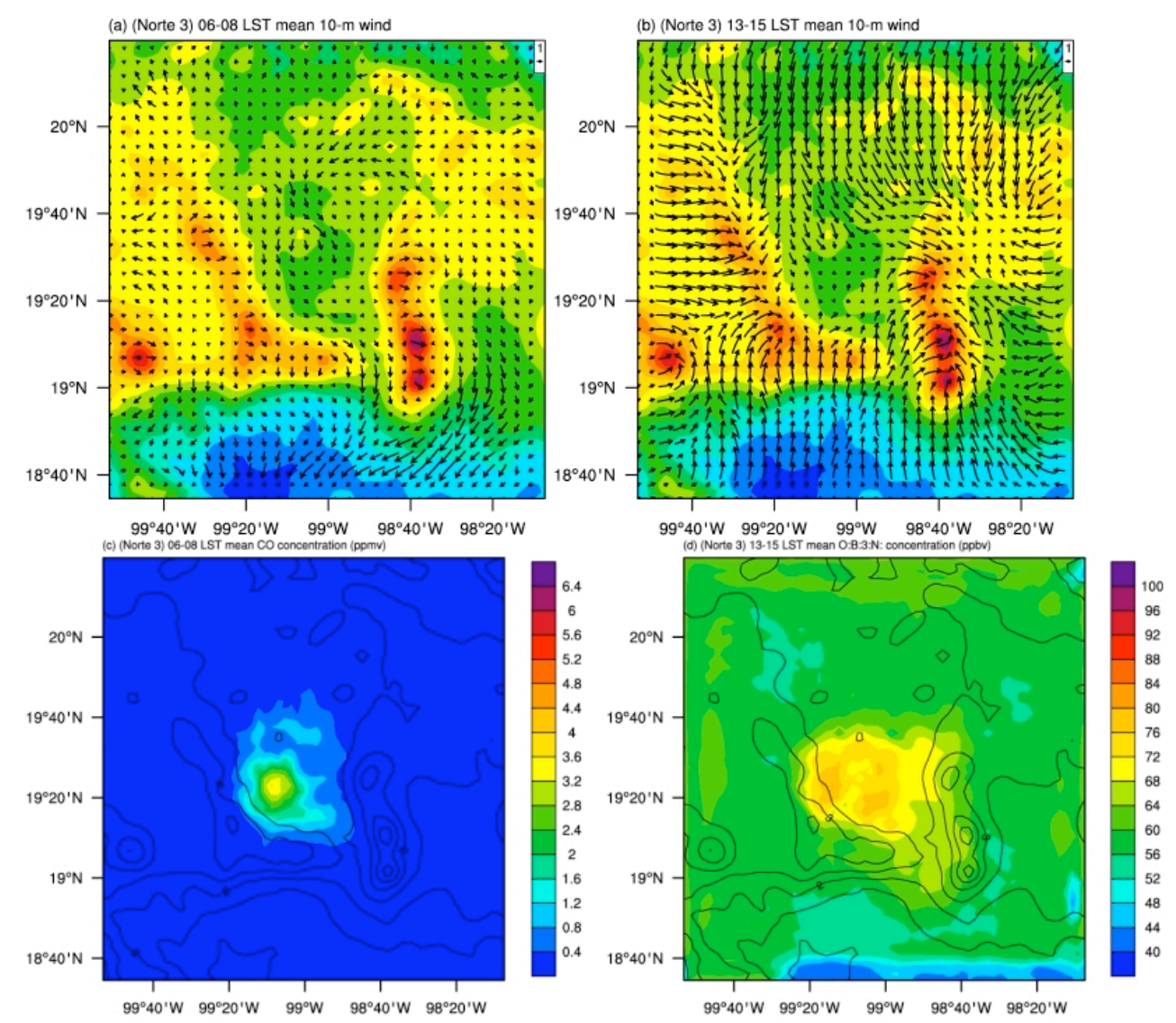

Fig. 13. Same as Fig. 7 except for the Norte 3 event (23 March through 25). 

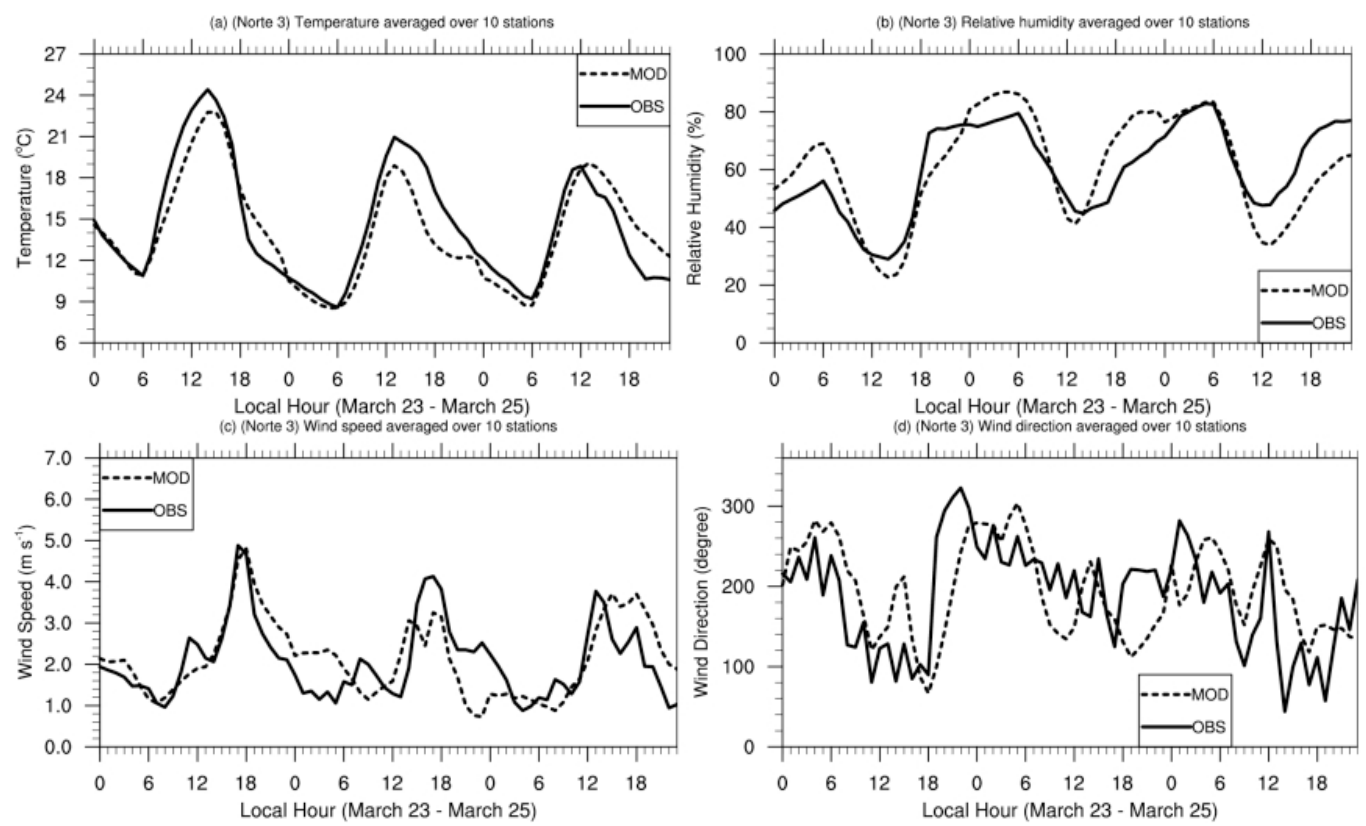

Fig. 14. Same as Fig. 8 except for the period of 00:00 LST 23 March through 23:00 LST 25 March (the Norte 3 event).
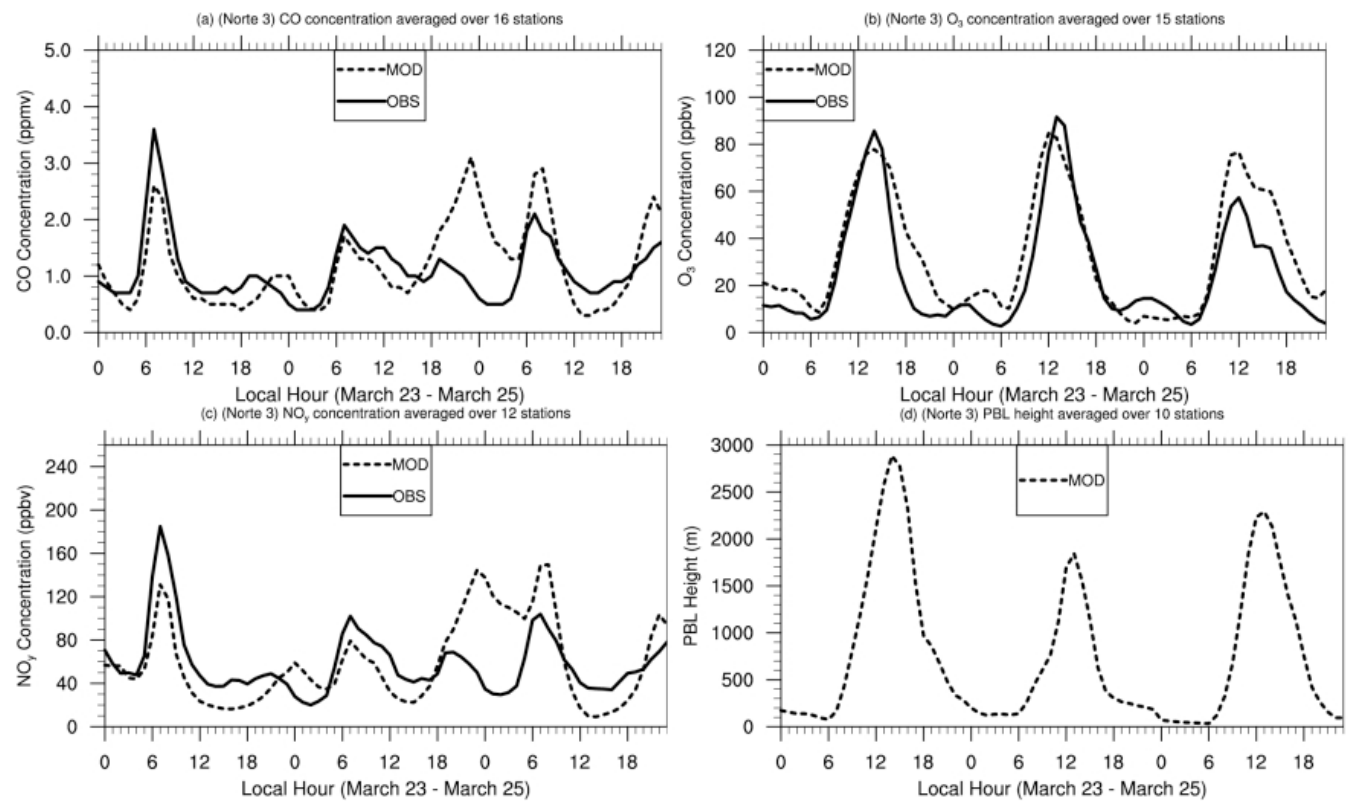

Fig. 15. Same as Fig. 9 except for the period of 00:00 LST 23 March through 23:00 LST 25 March (the Norte 3 event). 
Table 3. Performance statistics for predictions of $\mathrm{T}, \mathrm{RH}, \mathrm{WS}, \mathrm{WD}, \mathrm{CO}, \mathrm{O}_{3}, \mathrm{NO}, \mathrm{NO}_{2}$, and $\mathrm{NO}_{\mathrm{y}}$ for weather episodes.

\begin{tabular}{ccccccccccc}
\hline & & $\mathrm{T}^{c}$ & $\mathrm{RH}$ & $\mathrm{WS}$ & $\mathrm{WD}$ & $\mathrm{CO}^{\mathrm{d}}$ & $\mathrm{O}_{3}$ & $\mathrm{NO}$ & $\mathrm{NO}_{2}$ & $\mathrm{NO}_{\mathrm{x}}^{\mathrm{e}}$ \\
\hline \multirow{5}{*}{$\mathrm{O}_{3}$-South } & $\mathrm{MeanX}_{o}^{\mathrm{a}}$ & 17.1 & 39.9 & 1.9 & 181. & 1.3 & 31.8 & 33.3 & 36.6 & 69.9 \\
& $\mathrm{MeanX}_{m}^{\mathrm{a}}$ & 16.3 & 39.6 & 2.4 & 192. & 1.2 & 33.7 & 24.0 & 37.3 & 62.5 \\
& $\mathrm{CC}^{\mathrm{b}}$ & 0.95 & 0.80 & 0.54 & 0.34 & 0.55 & 0.81 & 0.52 & 0.50 & 0.57 \\
& $\mathrm{ANB}^{\mathrm{b}}$ & -4.7 & -0.8 & 28.1 & 5.8 & -9.0 & 5.8 & -28. & 1.8 & -10. \\
& $\mathrm{MeanX}_{o}$ & 17.6 & 42.1 & 2.4 & 185. & 1.3 & 31.9 & 32.0 & 35.8 & 67.8 \\
$\mathrm{O}_{3}$-North & $\mathrm{MeanX}_{m}$ & 17.3 & 36.3 & 3.2 & 181. & 1.2 & 34.8 & 21.2 & 35.6 & 57.7 \\
& $\mathrm{CC}$ & 0.93 & 0.80 & 0.65 & 0.23 & 0.49 & 0.68 & 0.40 & 0.39 & 0.45 \\
& $\mathrm{ANB}(\%)$ & -1.4 & -14. & 32.3 & -2.2 & -13. & 9.1 & -34. & -0.8 & -15. \\
& $\mathrm{MeanX}$ & 16.1 & 55.2 & 2.1 & 194. & 1.0 & 32.6 & 21.8 & 31.8 & 53.5 \\
& $\mathrm{MeanX}$ & 15.7 & 53.8 & 2.4 & 204. & 1.1 & 34.8 & 18.4 & 34.1 & 54.9 \\
& $\mathrm{CC}$ & 0.93 & 0.84 & 0.48 & 0.34 & 0.38 & 0.81 & 0.33 & 0.29 & 0.38 \\
& $\mathrm{ANB}(\%)$ & -2.6 & -2.4 & 18.6 & 4.8 & 2.4 & 6.8 & -15. & 7.5 & 0.8 \\
\hline
\end{tabular}

Subscripts ${ }^{\mathrm{ab}}$ are the same as in Table 1.

Table 4. Performance statistics for predictions of VOC species for weather episodes.

\begin{tabular}{|c|c|c|c|c|c|c|c|c|c|c|c|}
\hline & & V1 & $\mathrm{V} 2$ & V3 & V4 & V5 & V6 & V7 & V8 & V9 & V10 \\
\hline \multirow{4}{*}{$\mathrm{O}_{3}$-South } & MeanX $X_{o}^{\mathrm{a}}$ & 42.1 & 6.4 & 19.1 & 12.5 & 0.71 & 4.2 & 1.8 & 12.8 & 4.1 & 1.3 \\
\hline & MeanX $X_{m}^{\mathrm{a}}$ & 18.0 & 6.0 & 16.4 & 14.9 & 0.56 & 2.5 & 1.1 & 11.1 & 3.5 & 2.8 \\
\hline & $\mathrm{CC}^{\mathrm{b}}$ & 0.28 & 0.53 & 0.41 & 0.28 & 0.18 & 0.46 & 0.51 & 0.44 & 0.50 & 0.57 \\
\hline & $\operatorname{ANB}(\%)^{\mathrm{b}}$ & -55 & 0. & -7 & 24. & -17 & -36 & -35 & -9 & -12 & 127. \\
\hline \multirow{4}{*}{$\mathrm{O}_{3}$-North } & MeanX $_{o}$ & 35.1 & 5.7 & 17.7 & 11.1 & 0.59 & 4.6 & 1.6 & 12.0 & 3.8 & 1.1 \\
\hline & MeanX $X_{m}$ & 20.6 & 5.5 & 18.1 & 15.0 & 0.64 & 2.2 & 1.1 & 11.1 & 3.8 & 2.8 \\
\hline & $\mathrm{CC}$ & 0.30 & 0.62 & 0.41 & 0.23 & 0.32 & 0.50 & 0.47 & 0.42 & 0.50 & 0.57 \\
\hline & $\mathrm{ANB}(\%)$ & -41 & -2 & 5. & 38. & 9. & -50 & -30 & -6 & 3. & 168. \\
\hline \multirow{4}{*}{ Norte } & MeanX $_{o}$ & 40.5 & 6.0 & 12.5 & 11.3 & 0.58 & 4.3 & 1.2 & 10.0 & 3.0 & 0.7 \\
\hline & MeanX $_{m}$ & 11.6 & 4.0 & 10.7 & 10.2 & 0.40 & 1.6 & 0.8 & 7.7 & 2.3 & 1.9 \\
\hline & $\mathrm{CC}$ & 0.08 & -0.1 & 0.06 & -0.2 & 0.12 & 0.36 & 0.30 & 0.19 & 0.40 & 0.35 \\
\hline & $\mathrm{ANB}(\%)$ & -75 & -24 & -14 & -7 & -31 & -59 & -34 & -22 & -22 & 177. \\
\hline
\end{tabular}

Subscripts $^{\mathrm{ab}}$ are the same as in Table $1 . \mathrm{V} 1$ to V10 are the same as in Table 2.

for the period of 18:00 LST 24 March through 06:00 LST 25 March when the model simulations not only overestimate the observations but also are out of phase with the observations. This is the time period when the model underestimates the temperature by $1-2^{\circ} \mathrm{C}$ and overestimates the relative humidity by $5-10 \%$ with the simulated wind speed and direction nearly out of phase with the observations (Fig. 14). It is possible that a small-scale weather system developed during the time period in association with the passing cold front and the model failed to capture it. Similar discussions also apply to $\mathrm{NO}_{\mathrm{y}}$ (Fig. 15c). In terms of $\mathrm{O}_{3}$ concentrations, the model simulations agree well with the observations except for an overestimate during the daytime hours of 25 March (Fig. 15b). On this day, clouds developed and rainfall was recorded at T0 (de Foy et al., 2008) and thus wet deposition of chemical species and their interaction with cloud particles became important. This version of WRF/Chem does not have these capabilities. The simulated PBL peak height during this Norte event is the lowest at $1500 \mathrm{~m}$ on 24 March with some recovery on 25 March (Fig. 15d). Such a distribution appears to agree with the wind profiler measurements in Shaw et al. (2007) who also show lower PBL height on March 24 and 25.

\subsubsection{Performance statistics}

The model performance for all the events combined under each weather episode is presented in Table 3. In terms of meteorological variables, except for the differences in the mean values, the correlation coefficients and ANBs are similar to 
each other for the same variable under all weather episodes. They are also consistent with the correlation coefficients and ANBs for all days (see Table 1). This suggests that the model performance does not differ among the weather episodes as far as meteorological variables are concerned. As before, WRF/Chem shows cold and dry biases and overestimates the surface wind speeds under each weather episode.

The correlation coefficients for $\mathrm{O}_{3}$ stay above 0.80 except for the $\mathrm{O}_{3}$-North episode for which the correlation coefficient is 0.68 (Table 3). Model overestimation of the observed $\mathrm{O}_{3}$ concentrations is indicated for all weather episodes as reflected by positive biases (Table 3 ). The correlation coefficients for the other chemical species are always the highest with the $\mathrm{O}_{3}$-South episode and then decrease steadily from the $\mathrm{O}_{3}$-North episode to the Norte events. Besides the importance of including contributions from regional transport, this may also suggest that the model needs to include wet deposition process and interaction with clouds particles and the associated mixing processes since the Norte events are usually associated with clouds and precipitation.

For each VOC species, the correlation coefficient and ANB are very similar to those for all day (see Tables 2 and 4). There are also no large differences in terms of correlation coefficients between the $\mathrm{O}_{3}$-South and $\mathrm{O}_{3}$-North episodes for each VOC species (Table 4). However, model degradation under the Norte events is noticeable for each VOC species as reflected by decreased correlation coefficients and increased magnitude of ANBs when compared to the $\mathrm{O}_{3}$-South and $\mathrm{O}_{3}$ North episodes. The exception is acetone and propanal for which the AVB is smaller under the Norte events.

\section{Conclusions}

This work presents WRF/Chem simulations of temperature, relative humidity, wind, and gaseous criteria pollutants $(\mathrm{CO}$, $\mathrm{O}_{3}, \mathrm{NO}, \mathrm{NO}_{2}$ and $\mathrm{NO}_{\mathrm{y}}$ ) during the MCMA-2006/MILAGRO field campaign. Comparison of the model simulations with measurements from the ground-based RAMA monitoring network is presented. Comparison between the observed and simulated VOC species at the T0 supersite during MILAGRO is also included. The model resolves reasonably well the observed surface temperature, relative humidity and wind speed during MILAGRO as reflected by the relatively high correlation coefficient and low average normalized biases. However, the model tends to underestimate surface temperatures and relative humidity during daytime while overestimate surface relative humidity during nighttime. These model deficiencies are attributable to several factors, including specifications of surface properties in the model, PBL height, model resolution, model physics, and local effects in urban environments. Noticeable discrepancies are identified between the model simulations and the observations in terms of surface wind direction. The observed surface winds during MILAGRO are mainly characterized by low wind speeds $\left(\leq 4 \mathrm{~m} \mathrm{~s}^{-1}\right)$. The realistic representation of wind direction under weak wind conditions is challenging for WRF/Chem as well as for other mesoscale models.

The chemical species $\left(\mathrm{CO}, \mathrm{O}_{3}, \mathrm{NO}, \mathrm{NO}_{2}\right.$ and $\left.\mathrm{NO}_{\mathrm{y}}\right)$ simulated by WRF/Chem compare favorably with the observations. The model performs especially well in resolving the observed $\mathrm{O}_{3}$ concentrations during MILAGRO. The simulated 10 VOC species at the T0 supersite compare generally favorably with the measurements although lower correlation coefficients and larger biases exist for propene, acetone and propanal, isoprene, and c10-aromatics.

The correlation coefficients are much lower during nighttime than daytime not only for chemical species but also for meteorological variables. This is in part related to lower fluctuations in meteorological variables and chemical concentrations at night. Case studies using combinations of available PBL schemes (YSU and MYJ) and LSMs (NOAH and RUC) do not show a preferred combination for reproducing the observations both during nighttime and daytime.

The model performs similarly in terms of the mean values and biases for weekdays and weekends regarding meteorological variables and chemical species, suggesting that the $15 \%, 25 \%$ and $10 \%$ reductions of the total emissions rates used for Saturday, Sunday and holidays, respectively, appear reasonable. Decreased correlation coefficients for $\mathrm{CO}, \mathrm{NO}$, and $\mathrm{NO}_{\mathrm{x}}$ from weekdays to weekends may suggest large uncertainties in the temporal distributions of the emissions rates for weekends.

Distinctive features associated with the three types of weather episodes during MILAGRO, $\mathrm{O}_{3}$-South, $\mathrm{O}_{3}$-North and $\mathrm{El}$ Norte events are represented by WRF/Chem reasonably well. The simulated meteorological variables at monitoring stations compare favorably with observations for all weather episodes. The model performs well for the $\mathrm{O}_{3}$-South episode but inferiorly for the El Norte events in resolving the observed chemical species.

This work used the emissions inventory compiled and gridded at the Molina Center for Energy and the Environment (MCE2) based on the official emissions inventory for the MCMA for the year 2004. The Emissions Inventory 2006 for the MCMA has been released (http://www.sma.df.gob. $\mathrm{mx} / \mathrm{sma} /$ index.php?opcion=26id=501). This updated official inventory includes hourly emissions per pollutant, per day of the week, per season of the year, and it is spatially disaggregated. Future work will use the updated emissions inventory once it is adjusted based on measurements from field campaigns, gridded, validated and ready for input into air quality models.

During MILAGRO, coordinated aircraft-based and ground-based measurements were made of gaseous pollutants, aerosol particles, and meteorological fields. This rich data set of measurements provides unprecedented opportunities for validating model simulations at various scales. As an initial step, we have evaluated the performance of WRF/Chem in resolving the dynamic fields and the 
concentrations and distributions of pollutants in the Mexico City using the RAMA measurements. Comparisons between the model simulations and aircraft observations during MILAGRO are under way and the results will be reported in a future work.

Acknowledgements. This work (LA-UR-06-7494) was supported by the Los Alamos National Laboratory through the Laboratory Directed Research Development (LDRD) Program (project number LDRD200500014DR). The authors would like to acknowledge the Molina Center for Energy and the Environment for providing the emissions inventory for the year 2004 used in this study. The authors are grateful to Miguel A. Zavala and Wenfang Lei for helpful comments and discussions. We are also grateful to Xuexi Tie and Jerome D. Fast for sharing their emissions inventory with us and to Benjamin de Foy for his assistance with processing the RAMA measurement data. Three anonymous reviewers are acknowledged for their constructive comments and suggestions in improving the manuscript. We thank the National Center for Atmospheric Research (NCAR) and the National Energy Research Scientific Computing Center (NERSC) for providing partial computing time for this work. The Los Alamos National Laboratory is operated by Los Alamos National Security, LLC., for the Department of Energy.

Edited by: J. Gaffney

\section{References}

Ackermann, I. J., Hass, H., Memmesheimer, M., Ebel, A., Binkowski, F. S., and Shankar, U.: Modal aerosol dynamics model for Europe: development and first applications, Atmos. Environ., 32(17), 2981-2999, 1998.

Alapaty, K., Olerud, D. T., Schere, K. L., and Hanna, A. F.: Sensitivity of regional oxidant model predictions to prognostic and diagnostic meteorological fields, J. Appl. Meteorol., 34, 17871801, 1995.

Bacon, D. P., Ahmad, N. N., Boybeyi, Z., Dunn, T. J., Hall, M. S., Lee, P. C. S., Sarma, R. A., Turner, M. D., Waight III, K. T., Young, S. H., and Zack, J. W: A dynamically adapting weather and dispersion model: the operational multiscale environmental model with grid adaptivity (OMEGA), Mon. Weather Rev., 128, 2044-2076, 2000.

Borja-Aburto, V. H., Loomis, D. P., Bangdiwala, S. I., Shy, C. M., and Rascon-Pacheco, R. A.: Ozone, suspended particulates, and daily mortality in Mexico City, Am. J. Epidemiol., 145(3), 258268, 1997.

Case, J. L., Crosson, W. L., Kumar, S. V., Lapenta, W. M., and Peters-Lidard, C. D.: Impacts of high-resolution land surface initialization on regional sensible weather forecasts from the WRF model, J. Hydrometeorol., 9, 1249-1266, 2008.

Chang, J. S., Middleton, P. B., Stockwell, W. R., Binkowski, F. S., and Byun, D.: The regional acid deposition model and engineering model, State-of-Science/Technology, Report 4, National Acid Precipitation Assessment Program, Washington, DC, 1989.

Chen, F. and Dudhia, J.: Coupling an advanced landsurface/hydrology model with the Penn State/NCAR MM5 modeling system. Part I: Model description and implementation, Mon. Weather Rev., 129, 569-585, 2001.
Cheng, W. Y. Y. and Steenburgh, W. J.: Evaluation of surface sensible weather forecasts by the WRF and the Eta models over the Western United States, Weather Forecast., 20, 812-821, 2005.

Chin, H.-N. S., Leach, M. J., Sugiyama, G. A., Leone Jr., J. M., Walker, H., Nasstrom, J. S., and Brown, M. J.: Evaluation of an urban canopy parameterization in a mesoscale model using VTMX and URBAN 2000 data, Mon. Weather Rev., 133, 20432068, 2005.

Chou, M.-D. and Suarez, M. J.: An efficient thermal infrared radiation parameterization for use in general circulation models, NASA Tech. Memo. 104606, 85 pp., 1994.

CAM - Comisión Ambiental Metropolitana: Inventario de emisiones de la zona metropolitana del valle de México, 2004, Secretaría del Medio Ambiente, Gobierno de México, Mexico City, 2006.

de Foy, B., Caetano, E., Magaña, V., Zitácuaro, A., Cárdenas, B., Retama, A., Ramos, R., Molina, L. T., and Molina, M. J.: Mexico City basin wind circulation during the MCMA-2003 field campaign, Atmos. Chem. Phys., 5, 2267-2288, 2005,

http://www.atmos-chem-phys.net/5/2267/2005/.

de Foy, B., Clappier, A., Molina, L. T., and Molina, M. J.: Distinct wind convergence patterns in the Mexico City basin due to the interaction of the gap winds with the synoptic flow, Atmos. Chem. Phys., 6, 1249-1265, 2006a, http://www.atmos-chem-phys.net/6/1249/2006/.

de Foy, B., Molina, L. T., and Molina, M. J.: Satellite-derived land surface parameters for mesoscale modeling of the Mexico City basin, Atmos. Chem. Phys., 6, 1315-1330, 2006b,

http://www.atmos-chem-phys.net/6/1315/2006/.

de Foy, B., Varela, J. R., Molina, L. T., and Molina, M. J.: Rapid ventilation of the Mexico City basin and regional fate of the urban plume, Atmos. Chem. Phys., 6, 2321-2335, 2006c, http://www.atmos-chem-phys.net/6/2321/2006/.

de Foy, B., Lei, W., Zavala, M., Volkamer, R., Samuelsson, J., Mellqvist, J., Galle, B., Martinez, A.-P., Grutter, M., Retama, A., and Molina, L. T.: Modeling constraints on the emission inventory and on vertical diffusion for $\mathrm{CO}$ and $\mathrm{SO}_{2}$ in the Mexico City Metropolitan Area using Solar FTIR and Zenith Sky UV Spectroscopy, Atmos. Chem. Phys., 7, 781-801, 2007, http://www.atmos-chem-phys.net/7/781/2007/.

de Foy, B., Fast, J. D., Paech, S. J., Phillips, D., Walters, J. T., Coulter, R. L., Martin, T. J., Pekour, M. S., Shaw, W. J., Kastendeuch, P. P., Marley, N. A., Retama, A., and Molina, L. T.: Basinscale wind transport during the MILAGRO field campaign and comparison to climatology using cluster analysis, Atmos. Chem. Phys., 8, 1209-1224, 2008, http://www.atmos-chem-phys.net/8/1209/2008/.

Doran, J. C., Abbott, S., Archuleta, J., Bian, X., Chow, J., Coulter, R. L., de Wekker, S. F. J., Edgerton, S., Elliott, S., Fernandez, A., Fast, J. D., Hubbe, J. M., King, C., Langley, D., Leach, J., Lee, J. T., Matin, T. J., Martinez, D., Martinez, J. L., Mercado, G., Mora, V., Mulhearn, M., Pena, J. L., Petty, R., Porch, W., Russell, C., Salas, R., Shannon, J. D., Shaw, W. J., Sosa, G., Tellier, L., Templeman, B., Watson, J. G., White, R., Whiteman, C. D., and Wolfe, D.: The IMADA-AVER boundary-layer experiment in the Mexico City area, B. Am. Meteorol. Soc., 79, 2497-2508, 1998.

Doran, J. C. and Zhong, S.: Thermally driven gap winds into the Mexico City area, J. Appl. Meteorol., 39, 1330-1340, 2000. 
Dudhia, J.: Numerical study of convection observed during the winter monsoon experiment using a mesoscale two-dimensional model, J. Atmos. Sci., 46, 3077-3107, 1989.

Fast, J. D. and Zhong, S.: Meteorological factors associated with inhomogeneous ozone concentrations within the Mexico City basin, J. Geophys. Res., 103, 18927-18946, 1998.

Fast, J. D., Gustafson Jr., W. I., Easter, R. C., Zaveri, R. A., Barnard, J. C., Chapman, E. G., Grell, G. A., and Peckham, S. E.: Evolution of ozone, particulates, and aerosol direct radiative forcing in the vicinity of Houston using a fully coupled meteorology-chemistry-aerosol model, J. Geophys. Res., 111, D21305, doi:10.1029/2005JD006721, 2006.

Fast, J. D., de Foy, B., Rosas, F. A., Caetano, E., Carmichael, G., Emmons, L., Mckenna, D., Mena, M., Skamarock, W., Xie, T., Coulter, R. L., Barnard, J. C., Wiedinmyer, C., and Madronich, S.: A meteorological overview of the MILAGRO field campaigns, Atmos. Chem. Phys., 7, 2233-2257, 2007, http://www.atmos-chem-phys.net/7/2233/2007/.

Fortner, E. C., Zheng, J., Zhang, R., Berk Knighton, W., Volkamer, R. M., Sheehy, P., Molina, L., and André, M.: Measurements of volatile organic compounds using proton transfer reaction mass spectrometry during the MILAGRO 2006 Campaign, Atmos. Chem. Phys., 9, 467-481, 2009,

http://www.atmos-chem-phys.net/9/467/2009/.

Grell, G. A., Peckham, S. E., Schmitz, R., McKeen, S. A., Frost, G., Skamarock, W. C., and Eder, B.: Fully coupled "online" chemistry within the WRF model, Atmos. Environ., 39, 6957-6975, 2005.

Harley, R. A., Russell, A. G., McRae, G. J., Cass, G. R., and Seinfeld, J. H.: Photochemical modeling of the Southern California Air Quality Study, Environ. Sci. Technol., 27, 378-388, 1993.

Hong, S.-Y. and Pan, H.-L.: Nonlocal boundary layer vertical diffusion in a medium-range forecast model, Mon. Weather Rev., 124, 2322-2339, 1996.

Hong, S.-Y., Noh, Y., and Dudhia, J.: A new vertical diffusion package with an explicit treatment of entrainment processes, Mon. Weather Rev., 134, 2318-2341, 2006.

Instituto Nacional de Ecologia, INE: Tercer almanaque de datos y tendencias de la calidad del aire en nueve ciudades mexicanas, ISBN: 968-817-840-3, Mexico, 116 pp., 2007.

Janjic, Z. I.: The surface layer in the NCEP Eta Model, Eleventh Conference on Numerical Weather Prediction, American Meteorological Society, Norfolk, VA, 19-23 August, 1996.

Janjic, Z. I.: Nonsingular Implementation of the Mellor-Yamada Level 2.5 Scheme in the NCEP Meso Model, NCEP Office Note, No. 437, 61 pp., 2002.

Jazcilevich, A. D., García, A. R., and Ruíz-Suárez, L. G.: A study of air flow patterns affecting pollutant concentrations in the Central Region of Mexico, Atmos. Environ., 37, 183-193, 2003.

Lei, W., Zhang, R., Tie, X., and Hess, P.: Chemical characterization of ozone formation in the Houston-Galveston area, J. Geophys. Res., 109, D12301, doi:10.1029/2003JD004219, 2004.

Lei, W., de Foy, B., Zavala, M., Volkamer, R., and Molina, L. T.: Characterizing ozone production in the Mexico City Metropolitan Area: a case study using a chemical transport model, Atmos. Chem. Phys., 7, 1347-1366, 2007, http://www.atmos-chem-phys.net/7/1347/2007/.

Li, G., Zhang, R., Fan, J., and Tie, X.: Impacts of biogenic emissions on photochemical ozone production in Houston, Texas, J.
Geophys. Res., 112, D10309, doi:10.1029/2006JD007924, 2007.

Madronich, S.: Photodissociation in the Atmosphere, 1, actinic flux and the effects of ground reflections and clouds, J. Geophys. Res., 92, 9740-9752, 1987.

Mao, Q., Gautney, L. L., Cook, T. M., Jacobs, M. E., Smith, S. N., and Kelsoe, J. J.: Numerical experiments on MM5-CMAQ sensitivity to various PBL schemes, Atmos. Environ., 40, 3092 3110, 2006.

Mellor, G. L. and Yamada, T.: Development of a turbulence closure model for geophysical fluid problems, Rev. Geophys. Space Phys., 20, 851-875, 1982.

Mlawer, E. J., Taubman, S. J., Brown, P. D., Iacono, M. J., and Clough, S. A.: Radiative transfer for inhomogeneous atmosphere: RRTM, a validated correlated-k model for longwave, J. Geophys. Res., 102(D14), 16663-16682, 1997.

Molina, L. T. and Molina, M. J.: Air Quality in the Mexico Megacity: An Integrated Assessment, 408 pp, Kluwer Academic Publishers, Boston, USA, 2002.

Molina, L. T., Kolb, C. E., de Foy, B., Lamb, B. K., Brune, W. H., Jimenez, J. L., Ramos-Villegas, R., Sarmiento, J., ParamoFigueroa, V. H., Cardenas, B., Gutierrez-Avedoy, V., and Molina, M. J.: Air quality in North America's most populous city overview of the MCMA-2003 campaign, Atmos. Chem. Phys., 7, 2447-2473, 2007, http://www.atmos-chem-phys.net/7/2447/2007/.

Molina, L. T., Madronich, S., Gaffney, J. S., and Singh, H. B.: Overview of MILAGRO/INTEX-B Campaign, IGAC Newsletter, 38, 2-15, 2008.

Munoz-Alpizar, R., Blanchet, J.-P., and Quintanar, A. I.: Application of the NARCM model to high-resolution aerosol simulations: Case study of Mexico City basin during the Investigación sobre Materia Particulada y Deterioro Atmosférico-Aerosol and Visibility Research measurements campaign, J. Geophys. Res., 108(D15), 4462, doi:10.1029/2002JD003074, 2003.

Pielke, R. A. and Uliasz, M.: Use of meteorological models as input to regional and mesoscale air quality models - limitations and strengths, Atmos. Environ., 32, 1455-1466, 1998.

Raga, G. B. and Raga, A. C.: On the formation of an elevated ozone peak in Mexico City, Atmos. Environ., 34, 4097-4102, 2000.

Raga, G. B., Castro, T., and Baumgardner, D.: The impact of megacity pollution on local climate and implications for the regional environment: Mexico City, Atmos. Environ., 35, 18051811, 2001.

Romieu, I., Ramirez, M., Meneses, F., Ashley, D., Lemire, S., Colome, S., Fung, K., and Hernandez-Avila, M.: Environmental exposure to volatile organic compounds among workers in Mexico City as assessed by personal monitor and blood concentrations, Environ. Health Persp., 107(7), 511-515, 1999.

Satoh, M.: Conservative scheme for the compressible nonhydrostatic models with the horizontally explicit and vertically implicit time integration scheme, Mon. Weather Rev., 130, 1227-1245, 2002.

Schell, B., Ackermann, I. J., Hass, H., Binkowski, F. S., and Ebel, A.: Modeling the formation of secondary organic aerosol within a comprehensive air quality model system, J. Geophs. Res., 106, 28275-28293, 2001.

Schultz, D. M., Bracken, W. E., and Bosart, L. F.: Planetary- and synoptic-scale signatures associated with central American cold surges, Mon. Weather Rev., 126, 5-27, 1998. 
Seaman, N. L.: Meteorological modeling for air-quality assessments, Atmos. Environ., 34, 2231-2259, 2000.

Seigneur, C., Pun, B., Pai, P., Louis, J.-F., Solomon, P., Emery, C., Morris, R., Zahniser, M., Worsnop, D., Koutrakis, P., White, W., and Tombach, I.: Guidance for the performance evaluation of three-dimensional air quality modeling systems for particulate matter and visibility, J. Air Waste Manage., 50, 588-599, 2000.

Seinfeld, J. H. and Pandis, S. N.: Atmospheric Chemistry and Physics: From Air Pollution to Climate Change, 1326 pp., John Wiley, Hoboken, USA, 1998.

Shaw, W. J., Pekour, M. S., Coulter, R. L., Martin, T. J., and Walters, J. T.: The daytime mixing layer observed by radiosonde, profiler, and lidar during MILAGRO, Atmos. Chem. Phys. Discuss., 7, 15025-15065, 2007, http://www.atmos-chem-phys-discuss.net/7/15025/2007/.

Skamarock, W. C., Klemp, J. B., Dudhia, J., Gill, D. O., Barker, D. M., Wang, W., and Powers, J. G.: A Description of the Advanced Research WRF Version 2, 88 pp., NCAR Technical Note NCAR/TN-468+STR, 2006.

Smirnova, T. G., Brown, J. M., and Benjamin, S. G.: Performance of different soil model configurations in simulating ground surface temperature and surface fluxes, Mon. Weather Rev., 125, 1870-1884, 1997.

Smirnova, T. G., Brown, J. M., Benjamin, S. G., and Kim, D.: Parameterization of cold-season processes in the MAPS landsurface scheme, J. Geophys. Res., 105(D3), 4077-4086, 2000.

Snyder, B. J. and Strawbridge, K. B.: Meteorological analysis of the Pacific 2001 air quality field study, Atmos. Environ., 38, 57335743, 2004.

Stephens, S., Madronich, S., Wu, F., Olson, J. B., Ramos, R., Retama, A., and Muñoz, R.: Weekly patterns of Mexico City's surface concentrations of $\mathrm{CO}, \mathrm{NO}_{\mathrm{x}}, \mathrm{PM}_{10}$ and $\mathrm{O}_{3}$ during 19862007, Atmos. Chem. Phys., 8, 5313-5325, 2008,

http://www.atmos-chem-phys.net/8/5313/2008/.
Stockwell, W. R., Middleton, P., Chang, J. S., and Tang, X.: The second-generation regional acid deposition model chemical mechanism for regional air quality modeling, J. Geophys. Res., 95, 16343-16367, 1990.

Tie, X., S. Madronich, G.-H. Li, Z. Ying, R. Zhang, A. R. Garcia, J. Lee-Taylor, and Liu, Y.: Characterizations of chemical oxidants in Mexico City: A regional chemical dynamical model (WRFChem) study, Atmos. Environ., 41, 1989-2008, 2007.

West, J. J., Zavala, M. A., Molina, L. T., Molina, M. J., San Martini, F., McRae, G. J., Sosa-Iglesias, G., and Arriaga-Colina, J. L.: Modeling ozone photochemistry and evaluation of hydrocarbon emissions in the Mexico City metropolitan area, J. Geophys. Res., 109, D19312, doi:10.1029/2004JD004614, 2004.

Whiteman, C. D., Zhong, S., Bian, X., Fast, J. D., and Doran, J. C.: Boundary layer evolution and regional-scale diurnal circulations over the Mexico basin and Mexican plateau, J. Geophys. Res., 105(D8), 10081-10102, 2000.

Wild, O., Zhu, X., and Prather, M. J.: Fast-J: Accurate simulation of in- and below cloud photolysis in tropospheric chemical models, J. Atmos. Chem., 37, 245-282, 2000.

Winner, D. A. and Cass, G. R.: Modeling the long-term frequency distribution of regional ozone concentrations, Atmos. Environ., 33, 431-451, 1999.

Zaveri, R. A. and Peters, L. K.: A new lumped structure photochemical mechanism for large-scale applications, J. Geophys. Res., 104, 30387-30415, 1999.

Zaveri, R. A., Easter, R. C., Fast, J. D., and Peters, L. K.: Model for Simulating Aerosol Interactions and Chemistry (MOSAIC), J. Geophys. Res., 113, D13204, doi:10.1029/2007JD008782, 2008.

Zhao, J. and Zhang, R.: Proton transfer reaction rate constants between hydronium ion $\left(\mathrm{H}_{3} \mathrm{O}^{+}\right)$and volatile organic compounds (VOCs), Atmos. Environ., 38, 2177-2185 2004. 